158

$y$ LA-8673-PR

Progress Report

Or. 2299

$\int_{1}, 8^{8}$

Milliwatt Generator Project

April - September 1980

竞

MASTER

to

$\frac{7}{0}$

(1)

로 


\title{
Milliwatt Generator Project
}

\section{April - September 1980}

\author{
Compiled by
}

W. J. Maraman

Contributors

\author{
R. A. Kent, Project Leader \\ C. F. Frantz \\ C. C. Land \\ T. H. Feiertag \\ G. H. Rinehart \\ W. A. Stark
}

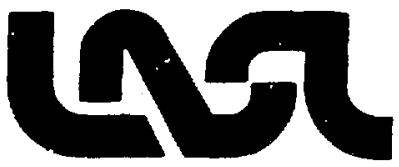

DISCLAIMER

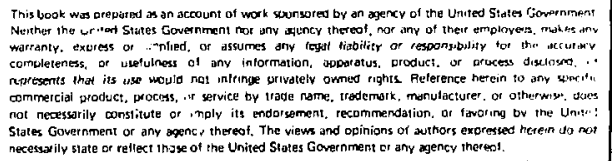




\title{
MILLIWATT GENERATOR PROJECT \\ ApriT - September 1980
}

\author{
Compiled by
}

W. J. Maraman

\section{Contributors}

R. A. Kent, Project Leader, C. E. Frantz, C. C. Land, T. H. Feiertag,

G. H. Rinehart, and W. A. Stark

\section{ABSTRACT}

This formal biannual report covers the effort related to the Milliwatt Generator Project (MWG) carried out for the Department of Energy, Office of Military Applications, by the Los Alamos Scientific Laboratory (LASL).

Most of the studies discussed here are of a continuing nature. Results and conclusions may change as the work continues. Published reference to the results cited in this report should not be made without the explicit permission of the person in charge of the work.

\section{SCHEDULE}

\section{A. General}

The main tasks to be accomplished prior to the initiation of WR production work at LASL are shown in Fig. I-I. This schedule has been agreed to in a series of meetings between LASL personnel and representatives from DOE/ALO, Sandia National Laboratory, Albuquerque (SNLA), Mounds Facility (MF), and the General Electric Nuclear Division (GEND). The primary tasks for LASL during FY 1980 were to (1) continue staffing and the training of personnel, (2) to develop the fuel processing flowsheet and characterize the fuel, (3) to produce 30 pressure burst-test units and ship them to MF and (4) to fabricate 30 LASL fueled heat sources for testing at LASL and GEND. Each of these tasks has been accomplished. The fuel processing development is discussed below in Section II. The welding development is described below in Section III. 


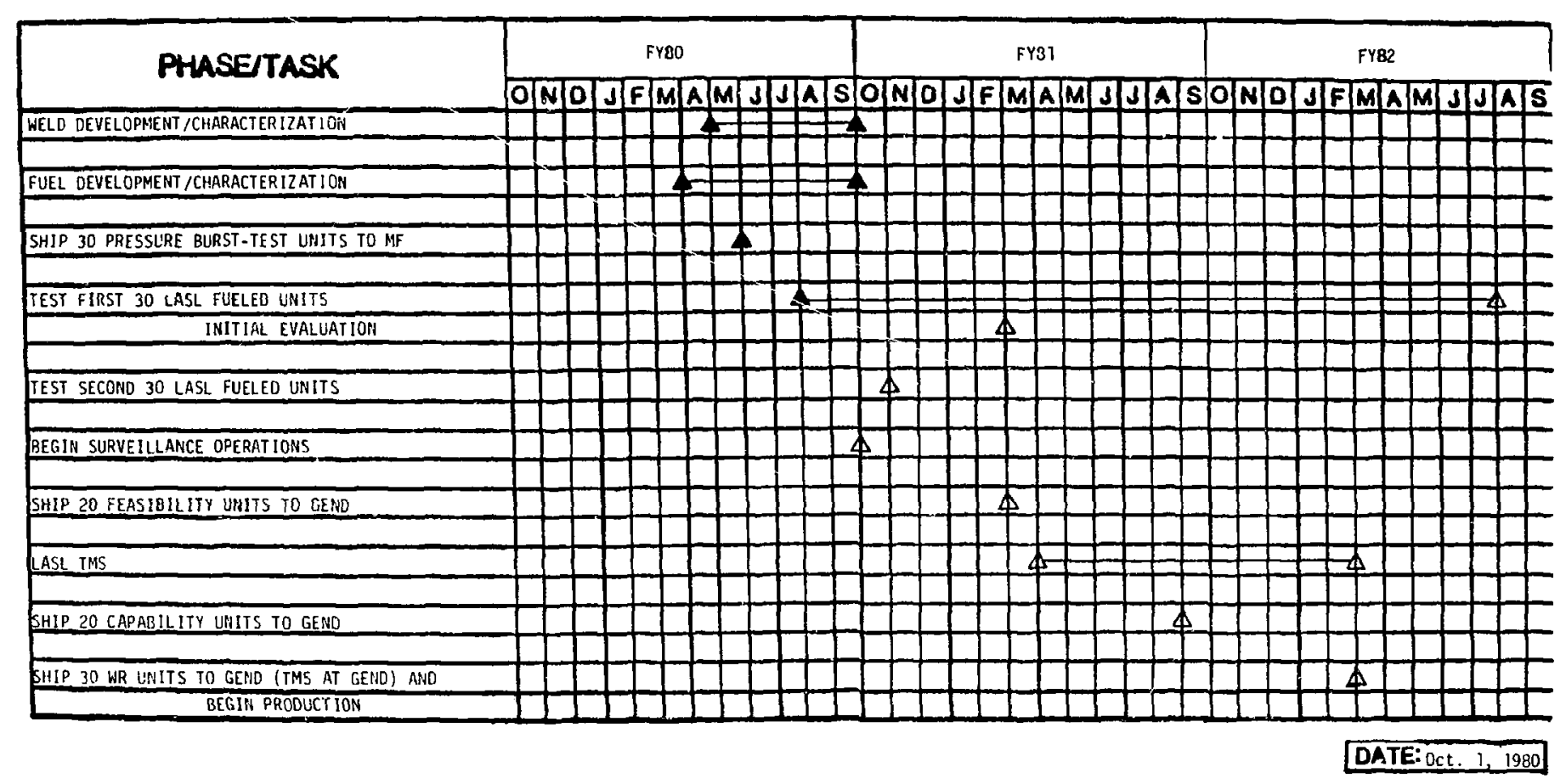

Fig. I-1. MWG project schedule. 


\section{B. Pressure Burst-Test Capsules}

Each lot of T-111 must be qualified by pressure burst testing. This test is to ensure that the strength member will be rupture-free in case of a fire $\left(1 \mathrm{~h}\right.$ at $\left.1010^{\circ} \mathrm{C}\right)$ at the end of capsule life, or when there is a maximum internal helium pressure due to plutonium-238 alpha decay.

A pressure-burst capsule consists of a strength member cap CTA-welded to a strength member body. The capsule contains a tantalum pellet to simulate the volume of the liner capsule and fuel. The cap is provided with a tantalum tube (1.52- $\mathrm{mm}$ diameter, $101.6-\mathrm{mm}$ long, with a $0.25-\mathrm{mm}$ orifice) that is electron beam-welded through the center of the cap. This tube is used to pressurize the capsule with helium and the tube is sealed. The amount of helium introduced is such that a preset pressure ( 2800 psi) is attained when the capsule is heated to about $1010^{\circ} \mathrm{C}$.

During 1980, LASL fabricated 50 pressure burst-test capsules. These are summarized in Tables I-1 through I-3. The capsules welded initially were used for LASL weld development efforts and 29 of those welded later were shipped to MF for testing. The results for some of the LASL units tested at MF are listed in Table I-4 and compared to those obtained for similar capsules welded at MF. These results indicate that the LASL welds are essentially the same as those performed at MF.

\section{Fueled Test Capsuies}

During FY1980, 54 Tiners were loaded with $\mathrm{PuO}_{2}$ fuel and welded. To date 43 of these fueled liners have been encapsulated ii strength members and 13 of these have been encapsulated in the outer ciad assemblies. These units were fabricated to establish welding parameters, checkout the nondestructive test procedures and to provide 30 specimens for impact, compatibility and vibration tests. The original project plan called for LASL to fabricate the MC2893A heat source, fueled at 4.0 watts, to be used in tine MC2730 Radioisotopic Thermoelectric Generator (RTG). Receritly, SNLA has requested that LASL also fabricate the MC3599 heat source, fueled at 4.5 watts, to he used in the MC.3500 RTG. Thus, 9 of the 30 LASL fueled test units were loaded at 4.5 watts instead of the 4.0 watts originally planned. The LASL results indicate that the heat sources can be fueled at 4.5 watts without a change in capsule dimensions. However, the void volume will be arpireciably reduced and this may affect the internal helium pressure as well as the impact and vibration response.

Twelve heat sources, 6 fueled at 4.0 watts and 6 fueled at 4.5 watts, were fabricated for vibration tests at GEND. The 4.5-watt units are summarized in Table I-5. Six units, 3 fueled at 4.0 watts and 3 fueled at 4.5 watts, will be impacted at LASL. The remaining 12 units, all fueled at 4.0 watts, are for compatibility tests at LASL. The compatibility test matrix is shown in Table I-6. Post-mortem examinations of the heat sources tested for 60 or $240 \mathrm{~d}$ will include metallographic, hardness, and chemical analyses of the containers and chemical and fines analyses of the fue?. If the results for the 6 units tested for 60 or $240 \mathrm{~d}$ indicate no compatibility problems, the other 6 units will remain in test for $2 y$.

\section{Test Data Evaluation}

The results of the pressure burst tests at MF, the vibration tests at GEND, and the impact and compatibility tests at LASL will be assenibled, correlated and distributed during February 1981. 
[ABLE $[-]$

LASL PRLSSURE BURSI-IESI CAPSULES $1-20$

\begin{tabular}{|c|c|c|c|c|c|c|c|c|}
\hline Identif & $\frac{\text { ation } 1}{\text { Body }}$ & $\frac{\text { Numbers }}{\text { PelTet }}$ & \multicolumn{3}{|c|}{$\begin{array}{l}\text { Glovebox Atmosphere } \\
(\mathrm{ppm})\end{array}$} & $\begin{array}{c}\text { He Leak } \\
\text { Rate } \\
\left(\mathrm{cm}^{3} / \mathrm{s} \times 10^{y}\right) \\
\end{array}$ & Radiograph & Status/Comments \\
\hline $\begin{array}{l}\text { LASL-01 } \\
\text { LASL-02 } \\
\text { LASL-03 } \\
\text { LASL-04 } \\
\text { LASL-05 } \\
\text { LASL-06 } \\
\text { LASL-07 } \\
\text { LASL-08 } \\
\text { LASL-09 } \\
\text { LASL-10 }\end{array}$ & $\begin{array}{l}1906 \\
1902 \\
1903 \\
1904 \\
1905 \\
1907 \\
1908 \\
1909 \\
1910 \\
1911\end{array}$ & $\begin{array}{l}1 \mathrm{fF} \\
8 \mathrm{~F} \\
9 \mathrm{~F} \\
10 \mathrm{~F} \\
11 \mathrm{~F} \\
12 \mathrm{~F} \\
14 \mathrm{~F} \\
16 \mathrm{~F} \\
17 \mathrm{~F} \\
19 \mathrm{~F}\end{array}$ & $\begin{array}{l}1.7 \\
1.2 \\
1.2 \\
1.2 \\
1.1 \\
1.1 \\
1.1 \\
1.2 \\
1.2 \\
2.0\end{array}$ & $\begin{array}{l}2.5 \\
2.5 \\
2.5 \\
2.5 \\
2.5 \\
2.5 \\
2.5 \\
2.5 \\
2.5 \\
2.5\end{array}$ & $\begin{array}{r}155 \\
155 \\
105 \\
105 \\
94 \\
122 \\
104 \\
99 \\
117 \\
145\end{array}$ & 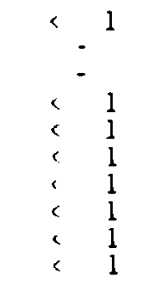 & $\begin{array}{c}\text { OK } \\
- \\
- \\
- \\
O K \\
O K \\
O K \\
- \\
O K \\
O K\end{array}$ & $\begin{array}{l}\text { Sectioned, good weld } \\
\text { Sectioned, weId off center, reuse pellet in LASL-36 } \\
\text { Sectioned, incomplete weld } \\
\text { Sectioned, good weld } \\
\text { Body marked by collet } \\
\text { Body marked by collet } \\
\text { Body marked by callet } \\
\text { Body marked by collet } \\
\text { Body marked by collet } \\
\text { Body marked by collet }\end{array}$ \\
\hline $\begin{array}{l}\text { LASL-11 } \\
\text { LASL-12 } \\
\text { LASL-13 } \\
\text { LA'SL-14 } \\
\text { LASL-15 } \\
\text { LASL-16 } \\
\text { LASL-17 } \\
\text { LASL-18 } \\
\text { LASL-19 } \\
\text { LASL-20 }\end{array}$ & $\begin{array}{l}1912 \\
1913 \\
1914 \\
1916 \\
1917 \\
1918 \\
1919 \\
1920 \\
1921 \\
1922\end{array}$ & $\begin{array}{l}20 \mathrm{~F} \\
2 \mathrm{FF} \\
23 \mathrm{~F} \\
25 \mathrm{~F} \\
26 \mathrm{~F} \\
66 \mathrm{~F} \\
80 \mathrm{~F} \\
81 \mathrm{~F} \\
82 \mathrm{~F} \\
83 \mathrm{~F}\end{array}$ & $\begin{array}{l}1.7 \\
1.7 \\
1.7 \\
3.1 \\
9.7 \\
0.3 \\
0.3 \\
0.3 \\
0.3 \\
0.3\end{array}$ & $\begin{array}{l}2.5 \\
2.5 \\
2.5 \\
2.0 \\
2.3 \\
2.5 \\
2.0 \\
2.0 \\
2.0 \\
2.0\end{array}$ & $\begin{array}{r}146 \\
146 \\
146 \\
100 \\
144 \\
18 \\
18 \\
17 \\
16 \\
16\end{array}$ & 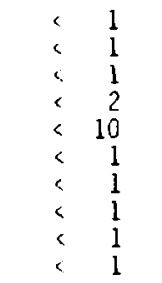 & $\begin{array}{l}\text { OK } \\
\text { OK } \\
- \\
- \\
\text { OK } \\
\text { OK } \\
\text { OK } \\
\text { OK } \\
\text { OK } \\
\text { OK }\end{array}$ & $\begin{array}{l}\text { Body marked by collet } \\
\text { Body marked by collet } \\
\text { Sectioned, good weld } \\
\text { bectioned, incomplete weld } \\
\text { Sectioned, good weld, reuse pellet in LASL-38 } \\
\text { To MF } \\
\text { Io MF } \\
\text { To MF } \\
\text { To MF }\end{array}$ \\
\hline
\end{tabular}

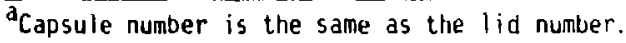


IABLE $1-2$

LASL PRESSURE BURST-TEST CAPSULES 21-40

\begin{tabular}{|c|c|c|c|c|c|c|c|c|}
\hline \multicolumn{2}{|c|}{$\frac{\text { Jdent ification }}{\text { Capsule Body }}$} & $\begin{array}{l}\text { Numbers } \\
\text { Pellet }\end{array}$ & \multicolumn{3}{|c|}{$\begin{array}{c}\text { Glovebox Atmosphere } \\
(\mathrm{ppm})\end{array}$} & $\begin{array}{c}\begin{array}{c}\text { He Leak } \\
\text { Rate } \\
\left(\mathrm{cm}^{3} / \mathrm{s} \times 10^{y}\right) \\
\end{array} \\
\end{array}$ & Radiography & Status/Comments \\
\hline $\begin{array}{l}\text { LASL }-21 \\
\text { LASL-22 } \\
\text { LASL-23 } \\
\text { LASL }-24 \\
\text { LASL-25 } \\
\text { LASL }-26 \\
\text { LASL-27 } \\
\text { LASL-28 } \\
\text { LASL }-29 \\
\text { LASL-30 }\end{array}$ & $\begin{array}{l}1923 \\
1924 \\
1925 \\
1926 \\
1927 \\
1928 \\
1929 \\
1930 \\
1931 \\
1932\end{array}$ & $\begin{array}{l}84 F \\
85 F \\
86 F \\
87 F \\
88 F \\
002 \\
003 \\
006 \\
007 \\
008\end{array}$ & $\begin{array}{l}0.3 \\
0.3 \\
0.3 \\
0.3 \\
0.2 \\
0.2 \\
0.2 \\
0.2 \\
0.2 \\
0.2\end{array}$ & $\begin{array}{l}2.0 \\
2.0 \\
2.0 \\
2.0 \\
2.0 \\
2.0 \\
2.0 \\
2.0 \\
2.0 \\
2.0\end{array}$ & $\begin{array}{l}16 \\
16 \\
16 \\
16 \\
16 \\
16 \\
16 \\
16 \\
16 \\
16\end{array}$ & $\begin{array}{ll}< & 1 \\
< & 1 \\
< & 1 \\
< & 1 \\
< & 1 \\
< & 1 \\
< & 1 \\
< & 1\end{array}$ & $\begin{array}{l}\text { OK } \\
\text { OK } \\
\text { OK } \\
\text { OK } \\
\text { OK } \\
\text { OK } \\
\text { OK } \\
\text { OK } \\
\text { OK } \\
\text { OK }\end{array}$ & 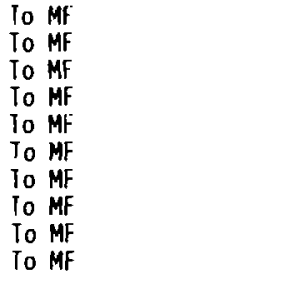 \\
\hline $\begin{array}{l}\text { LASL-31 } \\
\text { LASL-32 } \\
\text { LASL-33 } \\
\text { LASL-34 } \\
\text { LASL }-35 \\
\text { LASL }=36 \\
\text { LASL }-37 \\
\text { LASL-38 } \\
\text { LASL-39 } \\
\text { LASL- } 40\end{array}$ & $\begin{array}{l}1933 \\
1948 \\
1949 \\
1950 \\
1951 \\
1952 \\
1953 \\
1954 \\
1947 \\
1934\end{array}$ & $\begin{array}{r}009 \\
082 \\
081 \\
083 \\
084 \\
8 \mathrm{~F} \\
25 \mathrm{~F} \\
26 \mathrm{~F} \\
080 \\
010\end{array}$ & $\begin{array}{l}0.6 \\
0.9 \\
0.9 \\
0.9 \\
0.9 \\
0.4 \\
0.2 \\
0.2 \\
0.9 \\
1.0\end{array}$ & $\begin{array}{l}2.0 \\
2.0 \\
2.0 \\
2.0 \\
2.0 \\
2.0 \\
2.0 \\
2.0 \\
2.0 \\
2.0\end{array}$ & $\begin{array}{l}12 \\
12 \\
12 \\
12 \\
12 \\
21 \\
16 \\
12 \\
12 \\
12\end{array}$ & $\begin{array}{ll}< & 1 \\
< & 1 \\
< & 1 \\
< & 1 \\
< & 1 \\
< & 1 \\
< & 1 \\
< & 1 \\
< & 1\end{array}$ & $\begin{array}{l}\text { OK } \\
\text { OK } \\
\text { OK } \\
\text { OK } \\
\text { OK } \\
- \\
- \\
- \\
\text { OK } \\
\text { OK }\end{array}$ & $\begin{array}{l}\text { To MF } \\
\text { To MF } \\
\text { To MF } \\
\text { To MF. } \\
\text { To MF } \\
\text { Sectioned, good weid } \\
\text { Sectioned, good weld } \\
\text { Sectioned, good weid } \\
\text { To MF } \\
\text { To MF }\end{array}$ \\
\hline
\end{tabular}

Capsule number is the same as the lid number. 
TABLE 1-3

LASL PRESSURE BURST-TEST CAPSULES 41-50

\begin{tabular}{|c|c|c|c|c|c|}
\hline \multirow{2}{*}{$\begin{array}{l}\text { Identif } \\
\text { Capsule } \\
\end{array}$} & \multirow{2}{*}{$\begin{array}{l}\text { ation } \\
\text { Body }\end{array}$} & \multirow{2}{*}{$\frac{\text { Numbers }}{\text { Pellet }}$} & \multicolumn{3}{|c|}{$\begin{array}{c}\text { Glovebox Almosphe } \\
\text { (ppm) }\end{array}$} \\
\hline & & & $\underline{0_{2}}$ & $\mathrm{H}_{2} \mathrm{O}$ & $\mathrm{N}_{2}$ \\
\hline $\begin{array}{l}\text { LASL }-41 \\
\text { LASL }-42 \\
\text { LASL }-43 \\
\text { LASL }-44 \\
\text { LASL }-45 \\
\text { LASL }-46 \\
\text { LASL }-47 \\
\text { LASL-48 } \\
\text { LASL }-49 \\
\text { LASL }-50\end{array}$ & $\begin{array}{l}1935 \\
1936 \\
1937 \\
1938 \\
1939 \\
1940 \\
1942 \\
1944 \\
1945 \\
1946\end{array}$ & $\begin{array}{l}011 \\
012 \\
013 \\
014 \\
015 \\
016 \\
076 \\
077 \\
078 \\
079\end{array}$ & $\begin{array}{l}1.0 \\
1.0 \\
1.0 \\
1.0 \\
0.9 \\
0.9 \\
0.9 \\
0.9 \\
0.9 \\
0.9\end{array}$ & $\begin{array}{l}2.0 \\
2.0 \\
2.0 \\
2.0 \\
2.0 \\
2.0 \\
2.0 \\
2.0 \\
2.0 \\
2.0\end{array}$ & $\begin{array}{l}12 \\
12 \\
12 \\
12 \\
12 \\
12 \\
12 \\
12 \\
12 \\
12\end{array}$ \\
\hline
\end{tabular}

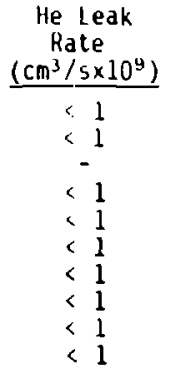

Radiography

Incomplete

$$
\text { OK }
$$

-

OK

OK

OK

OK

OK
Status/Comments

Radiography questionable, sectioned, weld OK To MF

Lid tipped during weld, lost capsule

To MF

To MF

To MF

To MF

To Mf

To MF

acapsule number is the sane as the lid number. 


\section{TABLE I-4}

\section{LOT 10 PRESSURE BURST-TESTS \\ PERFORMEO AT MF

$$
\text { (at } 1040^{\circ} \mathrm{C} \text { ) }
$$

LASL Capsules

\begin{tabular}{|c|c|c|}
\hline $\begin{array}{l}\text { Capsule } \\
\text { Number }\end{array}$ & $\begin{array}{l}\text { Internal } \\
\text { Pressure } \\
\text { (psia) }\end{array}$ & $\begin{array}{c}\text { Rupture } \\
\text { Time } \\
\text { (h) } \\
\end{array}$ \\
\hline LASL- 17 & 8002 & 12.69 \\
\hline LASL- 18 & 8002 & 51.82 \\
\hline LASL-20 & 8002 & 30.26 \\
\hline LASL-22 & 8005 & 2.25 \\
\hline \multirow[t]{2}{*}{ LASL-24 } & 8004 & 9.91 \\
\hline & 8003 & 21.59 \\
\hline
\end{tabular}

MF Capsules

\begin{tabular}{|c|c|c|}
\hline $\begin{array}{l}\text { Capsu le } \\
\text { Number }\end{array}$ & $\begin{array}{c}\text { Internal } \\
\text { Pressure } \\
\text { (psia) }\end{array}$ & $\begin{array}{c}\text { Rupture } \\
\text { Time } \\
\text { (h) }\end{array}$ \\
\hline МРТ $10-10$ & 8188 & 12.16 \\
\hline МРT 10-12 & 8188 & 33.09 \\
\hline МРТ 10- 18 & 8189 & 2.49 \\
\hline МРТ 10-19 & 8187 & 2.93 \\
\hline MPT 10-21 & 8190 & 11.87 \\
\hline МPТ 10-23 & 8188 & 18.21 \\
\hline \multirow[t]{2}{*}{ MPT 10-25 } & 8190 & 14.00 \\
\hline & 8188 & 15.38 \\
\hline
\end{tabular}


TABLE I-5

4.5 WATT TEST UNITS FOR GEND

\begin{tabular}{|c|c|c|}
\hline Clad & $\begin{array}{l}\text { Strength } \\
\text { Member }\end{array}$ & Liner \\
\hline $\begin{array}{l}03 \mathrm{~T}-\mathrm{H} 80 \\
04 \mathrm{~T}-\mathrm{H} 80 \\
05 \mathrm{~T}-\mathrm{H} 80 \\
06 \mathrm{~T}-\mathrm{H} 80 \\
07 \mathrm{~T}-\mathrm{H} 80 \\
08 \mathrm{~T}-\mathrm{H} 80\end{array}$ & $\begin{array}{l}1780 \\
1781 \\
1782 \\
1783 \\
1778 \\
1779\end{array}$ & $\begin{array}{l}1654 \\
1655 \\
1656 \\
1651 \\
1652\end{array}$ \\
\hline
\end{tabular}

\begin{tabular}{|c|c|}
\hline $\begin{array}{l}\text { Neutron } \\
\text { Emission } \\
(n / s) \\
\end{array}$ & Watts \\
\hline $\begin{array}{ll}36 & 809 \\
36 & 973 \\
37 & 096 \\
37 & 019 \\
37 & 024 \\
37 & 001\end{array}$ & $\begin{array}{l}4.596 \\
4.598 \\
4.597 \\
4.599 \\
4.598 \\
4.597\end{array}$ \\
\hline $\begin{array}{r}36987 \\
\pm \quad 96\end{array}$ & $\begin{array}{r}4.598 \\
\pm 0.001\end{array}$ \\
\hline
\end{tabular}

$\overline{{ }^{E} \text { ach heat source charge was } 11.108 \mathrm{~g} \mathrm{PuO}}, 0.61 \mathrm{~g} \mathrm{Y}$.

TABLE I-6

INITIAL LASL COMPATIBILITY

TEST MATRIX

\begin{tabular}{ccccc} 
& \multicolumn{3}{c}{ Number of Heat Sources Tested } \\
\cline { 3 - 4 } Test Temperature & $\frac{60 \text { days }}{600^{\circ} \mathrm{C}}$ & $\frac{240 \text { days }}{1}$ & $\frac{2 \text { years }}{\mathrm{a}}$ \\
$900^{\circ} \mathrm{C}$ & 1 & 1 & 2 \\
$1100^{\circ} \mathrm{C}$ & 1 & 1 & 2
\end{tabular}

\footnotetext{
${ }^{a}$ At end of test, one heat source will be sectioned, the other will be impacted and then sectioned.
} 


\section{FUEL PROCESSING}

A. Flowsheet

The LASL fuel processing flowsheet is shown in Fig. II-1. Most of the QA procedures for the fuel processing have been written and approved and personnel are being trained to perform these procedures. Three lots of feed powder, $616 \mathrm{~g}$ of $\mathrm{PuO}_{2}$, from the Savannah River Plant (SRP) were processed according to this flowsheet. The yield was $530 \mathrm{~g}$ of fuel granules or about $86 \%$, after analytical samples and processing losses were taken.

\section{B. Equipment Installation and Checkout}

1. Gloveboxes. Four gloveboxes dedicated to the MWG Project have been instaTled and brought into service. Most of these gloveboxes arr provided with inert-gas recirculating systems (helium for the welding boxes, argon otherwise) that normally provide atmospheres with less than 2 pom oxygen.

2. Glovebox Atmosphere Measurements. All gloveboxes, having inert-gas atmospheres, have been proviund with anatyzers to measure the oxygen and moisture contents of these atmospheres. The Teledyne Model $317 x$ analyzers are capable of continuous trace analyses in the range 0 to $10000 \mathrm{ppm}$ oxygen. The Ondyne Mocal 355 units are capabie of analyses in the range 0.5 to 20000 ppm water. In addition, the welding gloveboxes have been provided with vacuum Atmospheres Model AN-1 chromatographic units capable of measuring nitrogen in the range 3 to $30000 \mathrm{ppm}$ in the presence of argon and helium. Following the initial checkout of the welding gloveboxes, the typical atmospheres have been found to contain 1 ppm each of oxyger and water and. 30 ppm nitrogen. The MWG specifications for welding atmospheres are $25 \mathrm{ppm}$ oxygen, $60 \mathrm{ppm}$ water and $160 \mathrm{ppm}$ nitrogen.

3. Furnaces. Three modified Astro Model 1000A graphite-element furnaces have been received together with the attendent power supplies, programmers, and controllers. These units will be used for the oxygen-16 exchange of the PuO: feed powder, the seasoning of the feed granules at $1600^{\circ} \mathrm{C}$ and the drying of the granules after the final washing and screening operations. The furnaces met initial checkout specifications and they are being profiled for MWG operating temperature ranges.

In the interim, all furnaces (also Astro Model 1000Âs) used in the space projects have been brought under the MWG QA system w enable us to initiate the processing of MWG feed.

The Centorr tungsten-element vacuum furnace has been installed and tested to $1600^{\circ} \mathrm{C}$ at a vacuum of $5 \times 10^{-i}$ torr. This unit has been used to simultaneously heat $4 \mathrm{MWG}$ fueled strength members at $1350 \pm 5^{\circ} \mathrm{C}$.

4. Calorimetry. We have ordered 5 calorimeters from MF. These will be dedicated for the MuG project and are scheduled to be delivered to LASL about February 1981: Two units will be installed in the glovebox line to measure $\mathrm{PuO}_{2}$ feed material. The other 3 will be located outside the gloveboxes and will be used to measure the welded MWG heat sources.

A.t present, we are using an isothermal twin-tube calorimeter with a throughput of only 1 specimen per day. This unit will be used until the new calorimeters are delivered by MF. This calorimeter was used to measure 6 WR heat sources made at MF. The results are listed in Table II-I and are in excellant agreement with the MF calorimetry data. 


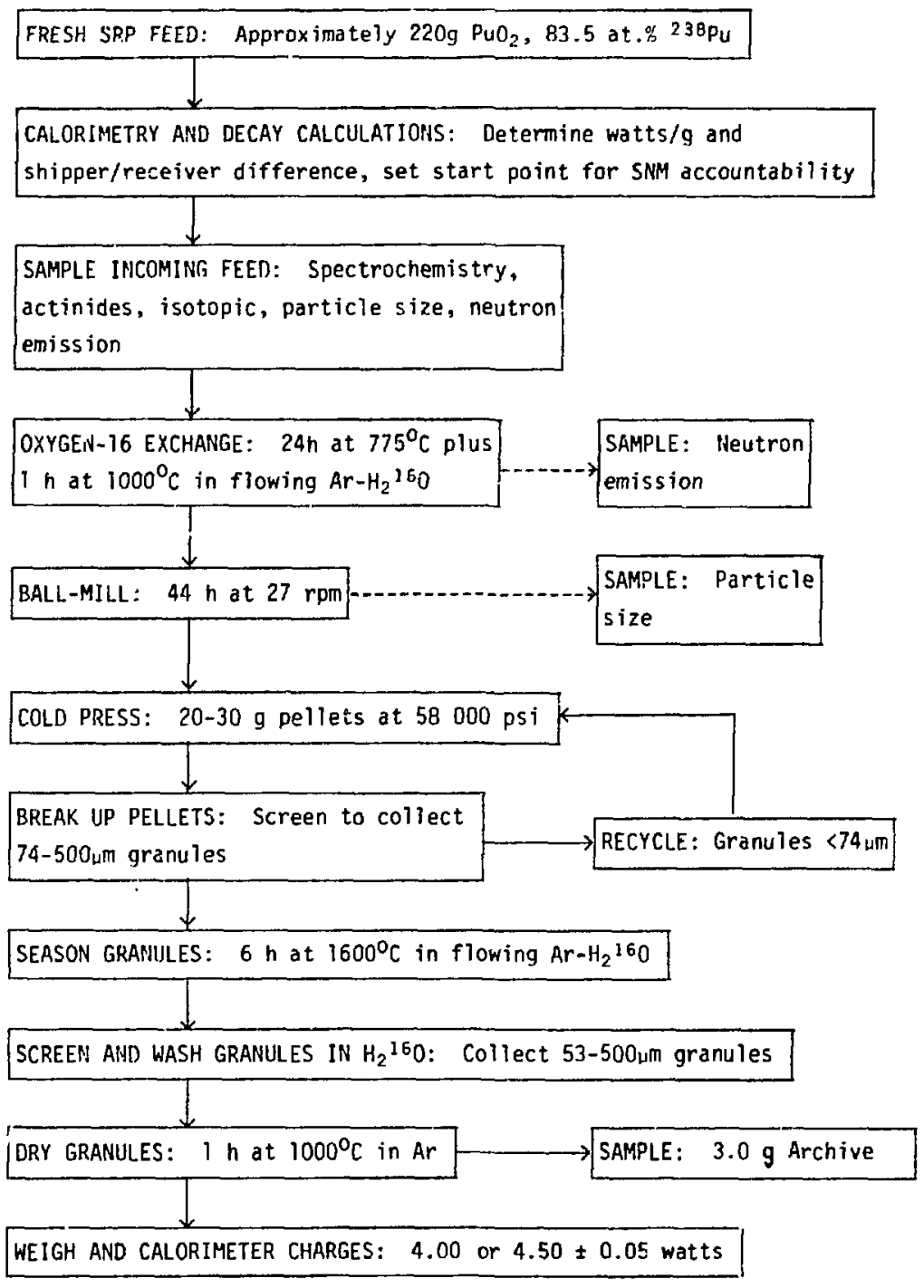

Fig. II-1. LASL MWG flowsheet - fue 1 processing. 
5. Neutron Emission Rate Measurements. Two thermal neutron counters (TNCS), designed and built at LASL, have been installed and tested. These units were used to measure the neutron emission rates for 6 WR heat sources made at MF. The data are listed in Table II-2 and compared to those measured at MF and at the LASL analytical chemistry group, CMB-1. The agreement is excellant and indicates that the LASL counters, insta:led for the MWG Project, will be adequate.

6. Miscellaneous Equipment. A Carver Model C 12-ton press, provided with an automated Enerpac Model PER 2035 hydreulic power unit, has been installed and tested, as have several Ainsworth Model Gamma III analytical balances. The Micromeritics Sedigraph Model 5000 GB particle size analyzer has bee! installed and tested. This unit is used to determine the particle size of SRP feed powder, both as-received and after ball-milling. It is also used to analyze the fines generated in heat sources during impact tests.

TABLE II-1

LASL ANALYSES OF MF WR ASSEMBLIES

CALORIMETRY

(watts/capsule)

\begin{tabular}{|c|c|c|c|}
\hline \multirow[b]{2}{*}{ MWG Capsule } & \multicolumn{2}{|c|}{ MF } & \multirow[b]{2}{*}{$\operatorname{LASL}^{b}$} \\
\hline & $10 / 4 / 78$ & $1 / 18 / 80^{a}$ & \\
\hline MAD-800-1-78 & 3.986 & 3.946 & $3.947 \pm 0.002$ \\
\hline MAD-801-1-78 & 3.984 & 3.944 & 3.945 \\
\hline MAD-802-1-78 & 3.989 & 3.949 & 3.951 \\
\hline MAD-803-1-78 & 3.988 & 3.948 & 3.948 \\
\hline MAD-804-1-78 & 3.999 & 3.959 & 3.959 \\
\hline MAO-805-i-78 & 3.992 & 3.952 & 3.952 \\
\hline
\end{tabular}

Corrected for decay assuming $\lambda=2.1617 \times 10^{-5}$ days -1 , $\Delta t=461$ days.

$b_{\text {Measured in January } 1980 .}$ 
TABLE II-2

LASL ANALYSES OF MF WR ASSEMBLIES

NEUTRON EMISSION

( $n / s$ per g sample)

\begin{tabular}{|c|c|c|c|}
\hline MWG Capsule & $\mathrm{MF}^{\mathrm{a}}$ & $\begin{array}{l}\text { Analytical } \\
\text { Group }\end{array}$ & $\begin{array}{l}\text { TWWG } \\
\text { Unit }\end{array}$ \\
\hline MAD-800-1-78 & 2725 & 2730 & 2740 \\
\hline MAD- $801-1-78$ & 2775 & 2740 & 2760 \\
\hline MAD- $802-1-78$ & 2765 & 2740 & 2730 \\
\hline MAD-803-1-78 & 2755 & 2750 & $2750^{b}$ \\
\hline MAD-804-1-78 & 2825 & 2790 & 2785 \\
\hline MAD-805-1-78 & 2785 & 2780 & 2790 \\
\hline
\end{tabular}

Each capsule contained $10.06 \mathrm{~g}$ Pu0.

${ }^{b}$ To be used for interim as calibration siandard.

C. Fuel Characterization-LASL Analyses

Three containers of SRP feed powder were recently processed at LASL. These were SRP Lot 438, Run 905911 (LASL Lot 48), SRP Lot 446, Run 908953 (LASL Lot 49), and SRP Lot 453, Run 910986 (LASL Lot 51). LASL spectrochemicai data for 2 of the as-received lots are listed in Table II-3. LASL isotopic values for these lots are listed in Table II-4. The as-received neutron emission rates were 16078 (Lot 48), 18202 (Lot 49), and $18980 \mathrm{n} / \mathrm{s}-\mathrm{g} 238 \mathrm{Pu}$ (Lot 51).

\section{WELDING AND NONDESTRUCTIVE TESTING}

A. Flowsheets III 1 . LASL flowsheet for welding the $T-111$ liners is diagramed in Fig. shown in $\mathrm{Fig}$ positioning, assembling, and welding sequence for the liners is strength members and Hastelloy-C clad members are shown in Fig. III-8 and Fig. III-9, respectively. The QA procedures for the assembly and welding of fueled heat sources have been written and approved and welding personnel are being trained. 
TABLE II-3

SPECTROCHEMICAL DATA FOR FEED LOTS

(ppm by weight)

\begin{tabular}{|c|c|c|c|c|}
\hline Species & Specification & $\begin{array}{c}\begin{array}{c}\text { Sensitivity } \\
\text { Limit }\end{array} \\
\end{array}$ & Lot 48 & Lot 51 \\
\hline $\mathrm{Al}$ & 70 & 5 & 110 & 300 \\
\hline B & 70 & 1 & $<^{a}$ & 3 \\
\hline $\mathrm{Ba}$ & 25 & 2 & $<$ & 15 \\
\hline $\mathrm{Bi}$ & 25 & 1 & $<$ & $<$ \\
\hline $\mathrm{Ca}$ & 250 & 3 & 300 & 20 \\
\hline $\mathrm{Cd}$ & 25 & 10 & $<$ & $<$ \\
\hline $\mathrm{Co}$ & 50 & 2 & $<$ & $<$ \\
\hline $\mathrm{Cr}$ & 150 & 5 & 30 & 100 \\
\hline $\mathrm{Cu}$ & 50 & 1 & 15 & 3 \\
\hline $\mathrm{Fe}$ & 500 & 5 & 170 & 490 \\
\hline $\mathrm{Mg}$ & 50 & 1 & 50 & 200 \\
\hline$M_{n}$ & 50 & 1 & 15 & 4 \\
\hline $\mathrm{Ni}$ & 100 & 5 & 20 & 60 \\
\hline $\mathrm{Pb}$ & 50 & 5 & 15 & 10 \\
\hline$S i$ & 100 & 5 & 80 & 240 \\
\hline Sn & 50 & 5 & 10 & 5 \\
\hline $\mathrm{Ta}$ & 150 & 100 & & $<$ \\
\hline $2 n$ & 100 & 5 & 10 & 20 \\
\hline
\end{tabular}

TABLE II -4

ISOTOPIC DATA FOR FEEO LOTS

(weight percent)

\begin{tabular}{|c|c|c|c|c|c|c|}
\hline \multirow{2}{*}{$\begin{array}{c}\mathrm{Pu} \\
\text { Isotope }\end{array}$} & \multicolumn{2}{|c|}{ Lot 48} & \multicolumn{2}{|c|}{ Lot 49} & \multicolumn{2}{|c|}{ Lot 51} \\
\hline & SR & LASL & $S R$ & LASL & $S R$ & LASLL \\
\hline $\begin{array}{l}238 \\
239 \\
240 \\
241 \\
247\end{array}$ & $\begin{array}{c}83.33^{\mathrm{a}} \\
14.13 \\
2.05 \\
0.47 \\
0.13\end{array}$ & $\begin{array}{r}83.19 \\
14.15 \\
2.06 \\
0.47 \\
0.12\end{array}$ & $\begin{array}{r}83.56 \\
13.93 \\
1.95 \\
0.42\end{array}$ & $\begin{array}{r}83.51 \\
13.98 \\
1.94 \\
0.42\end{array}$ & $\begin{array}{r}33.04 \\
14.36 \\
2.03 \\
0.43\end{array}$ & $\begin{array}{r}82.91 \\
14.45 \\
2.05 \\
0.44 \\
0.75\end{array}$ \\
\hline
\end{tabular}

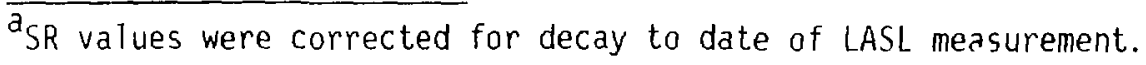




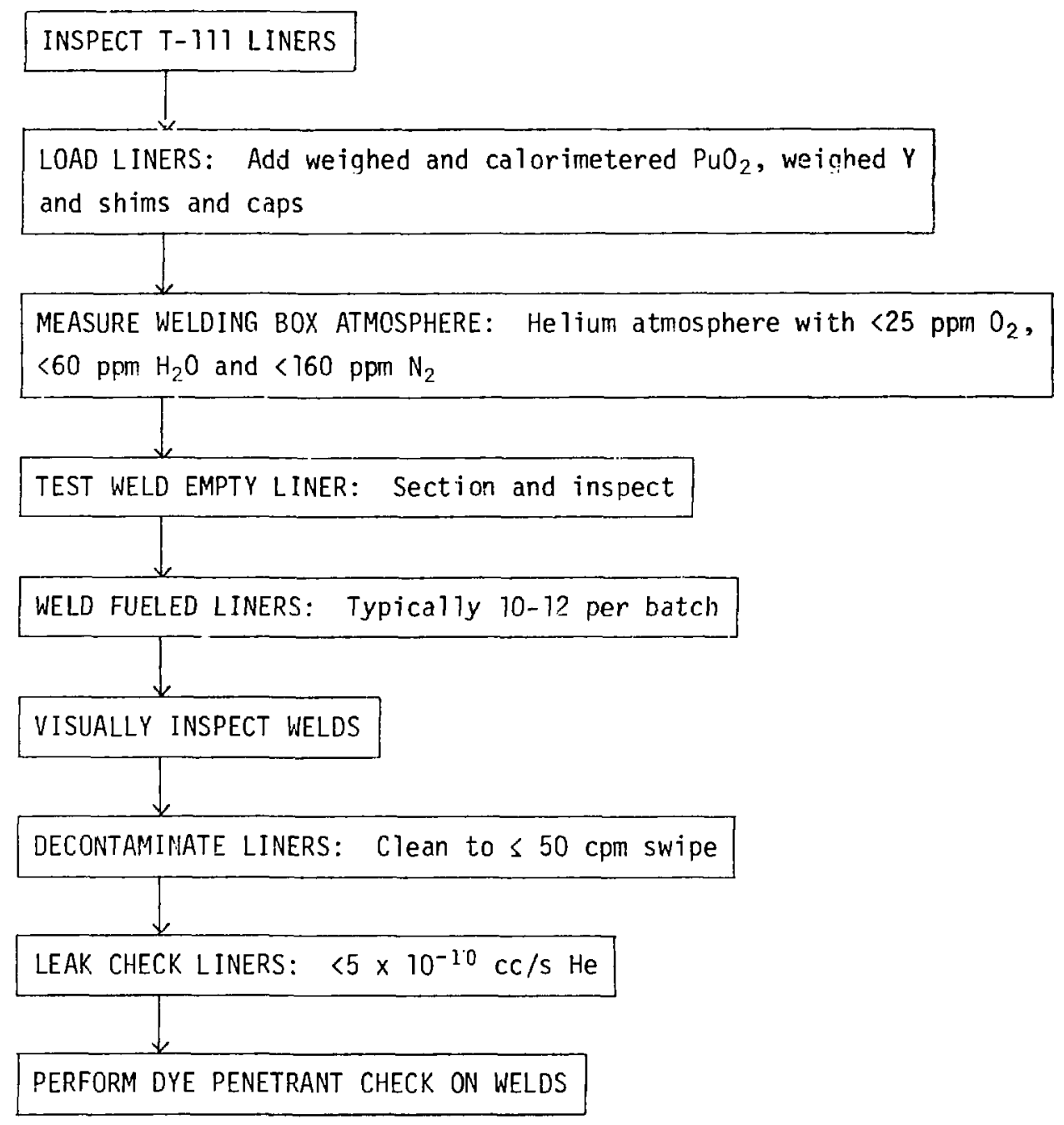

Fig. III-1. LASL MWG flowsheet - welding liners. 


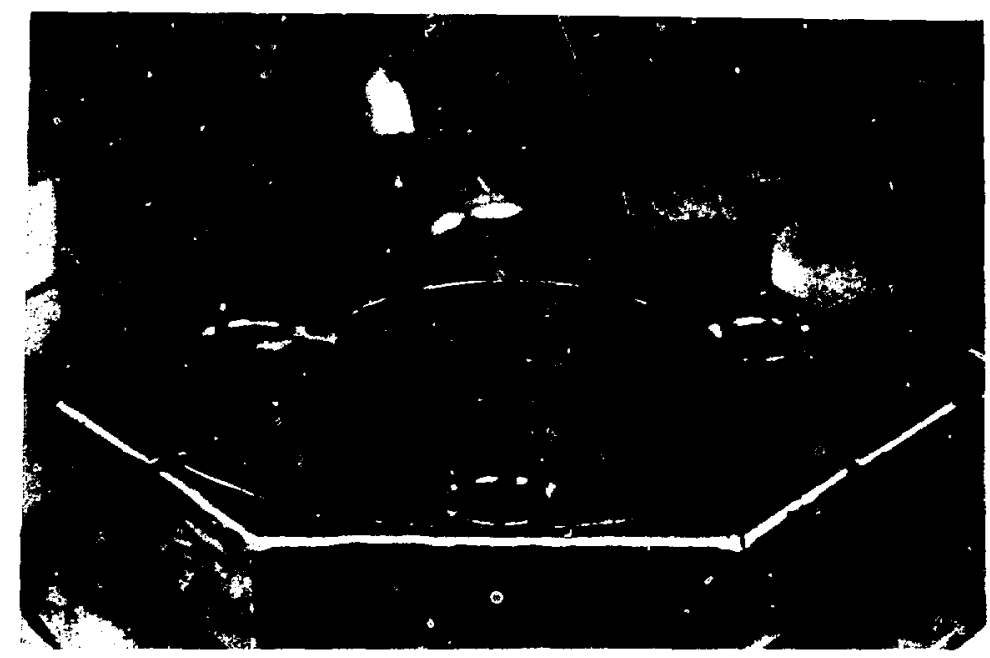

Fig. III-2. MWG liner positioned for welding.

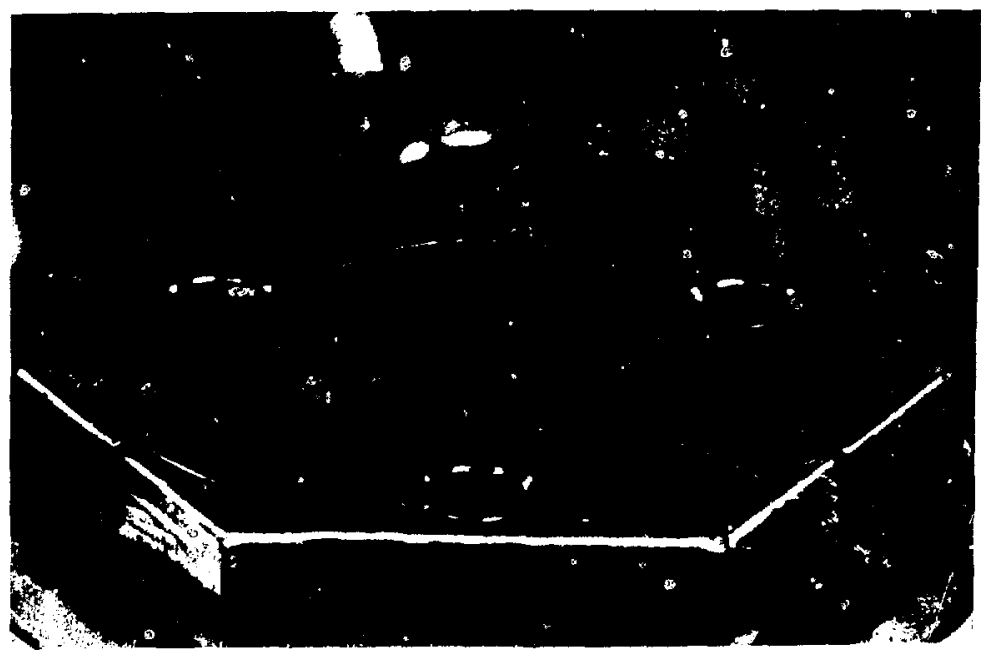

Fig. III-3. MWG liner filled with 4.5 watts $\mathrm{PuO}_{2}$ plus yttrium. 


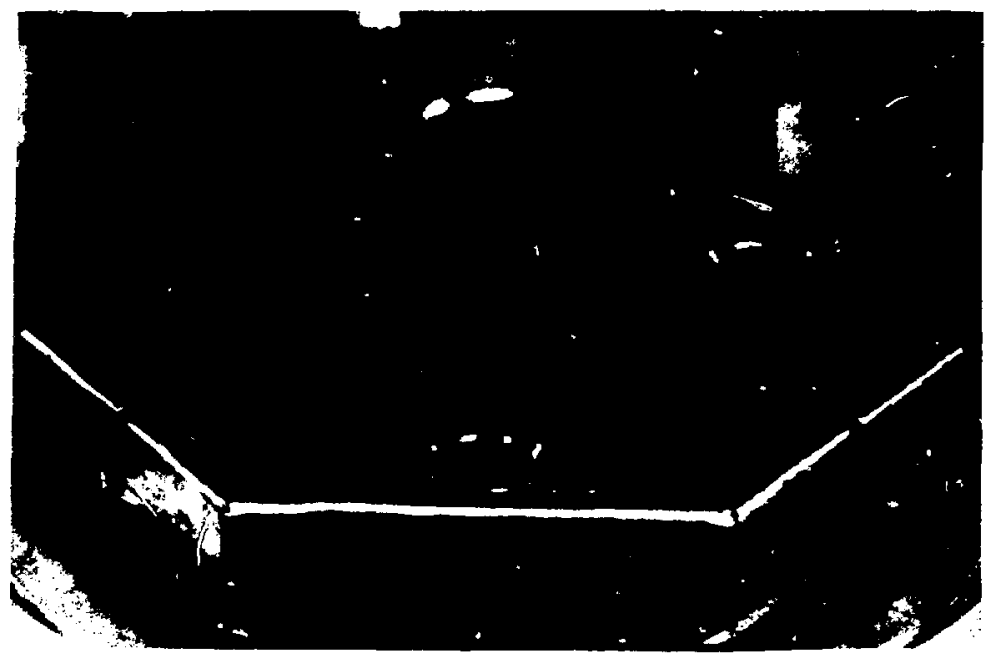

Fig. III-4. MWG liner filled with 4.5 watts $\mathrm{PuO}_{2}$ plus yttrium, after vibration.

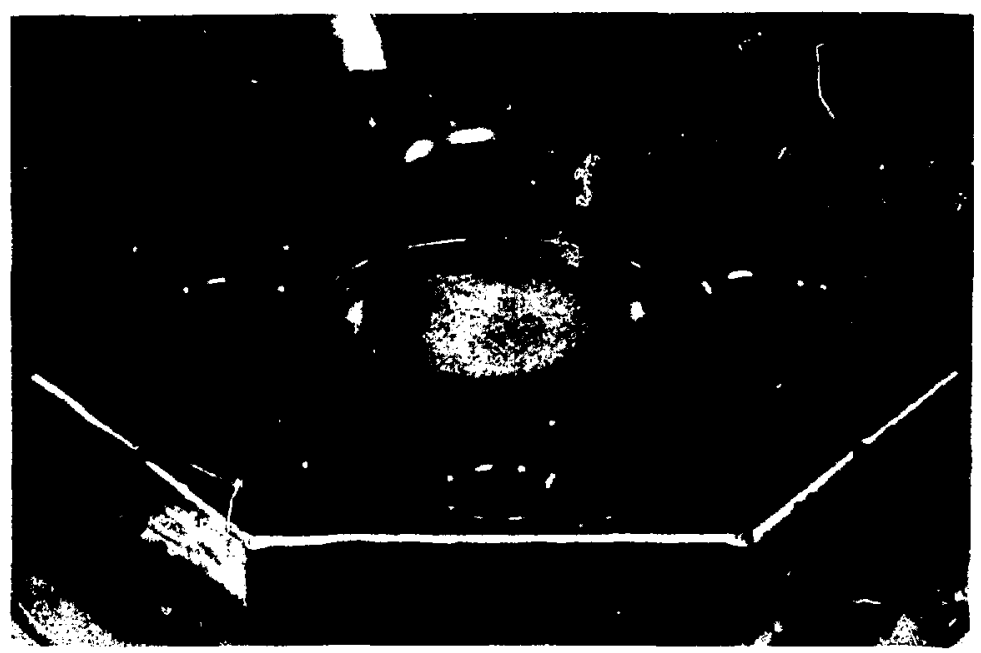

Fig. III-5. MWG liner fueled at 4.5 watts, shim in place. 


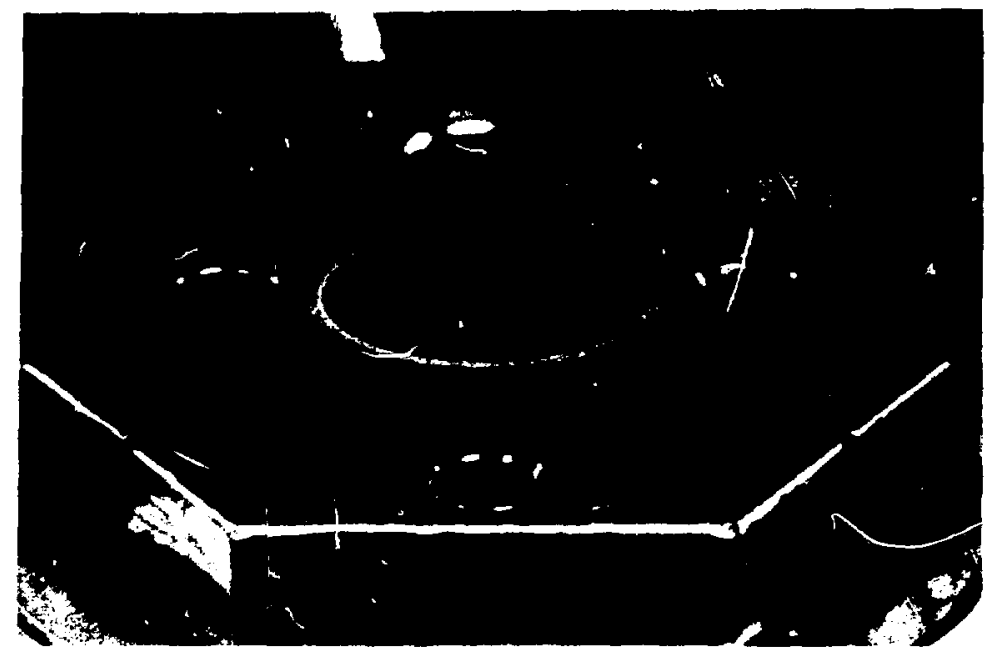

Fig. III-6. MWG liner fueled at 4.5 watts, cap in place.

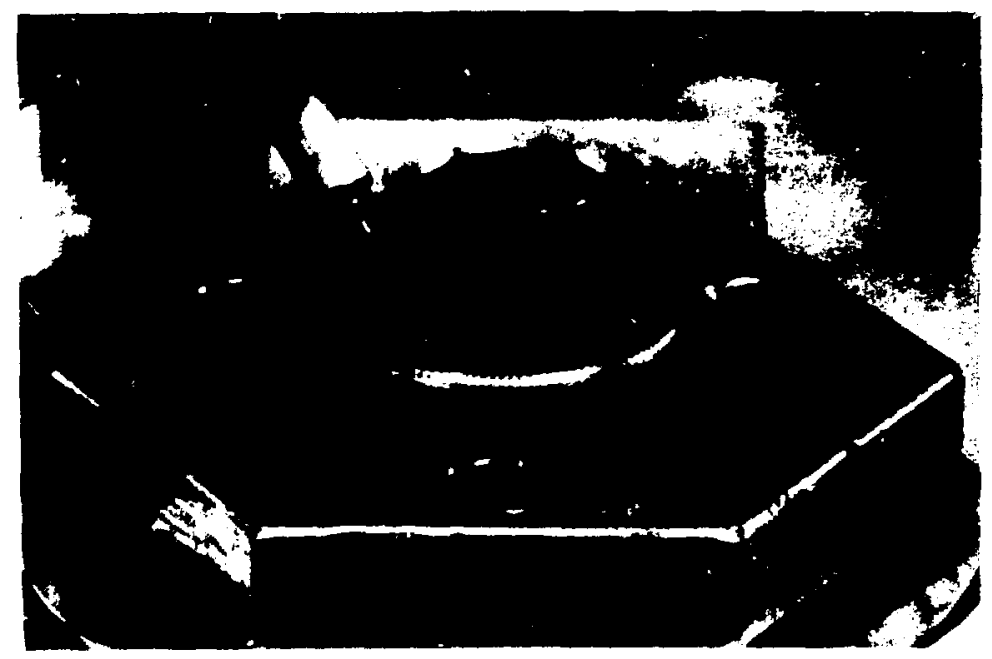

Fig. III-7. MWG liner fueled at 4.5 watts, cap welded. 


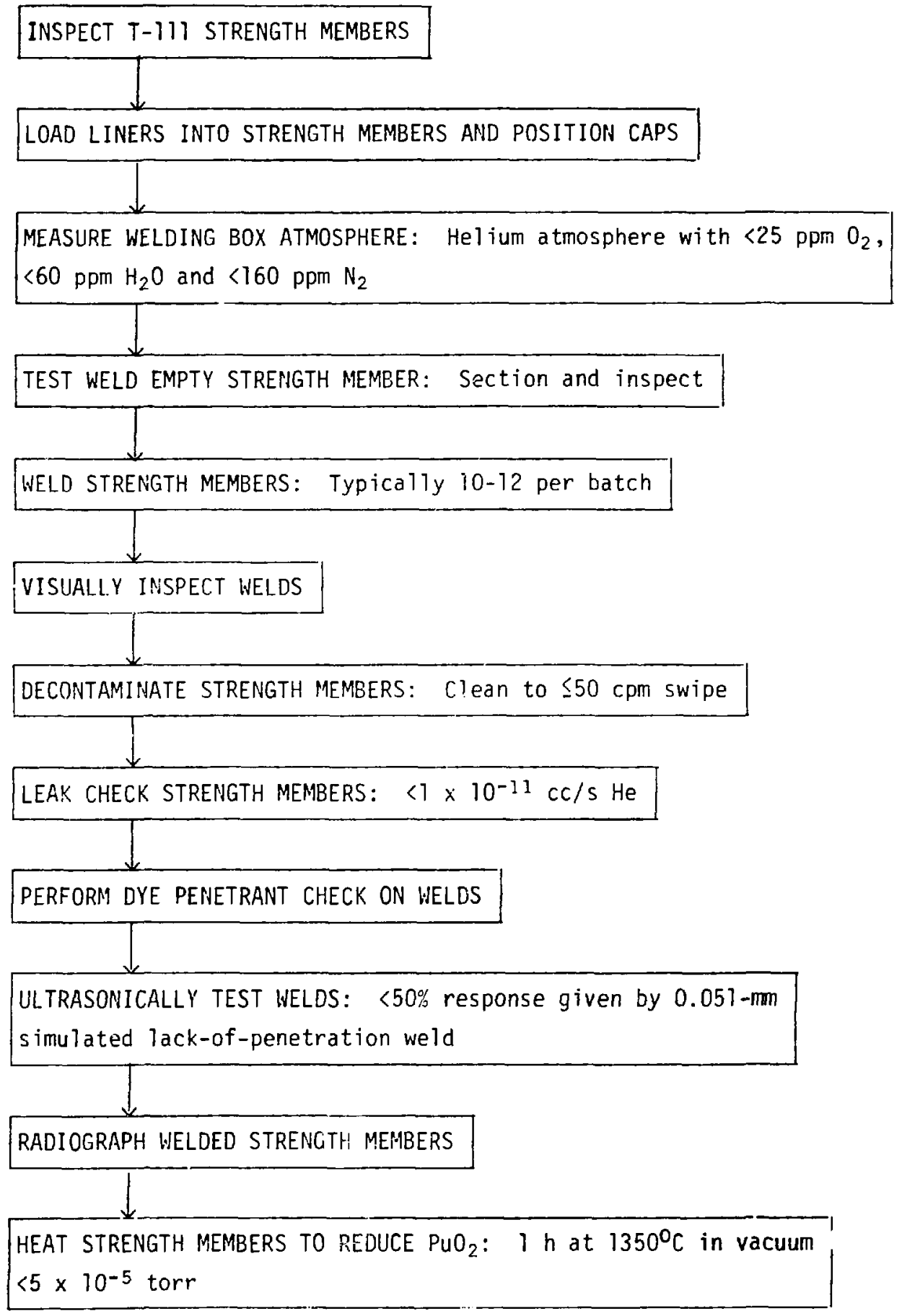

Fig. III-8. LASL MWG flowsheet - welding strength members. 


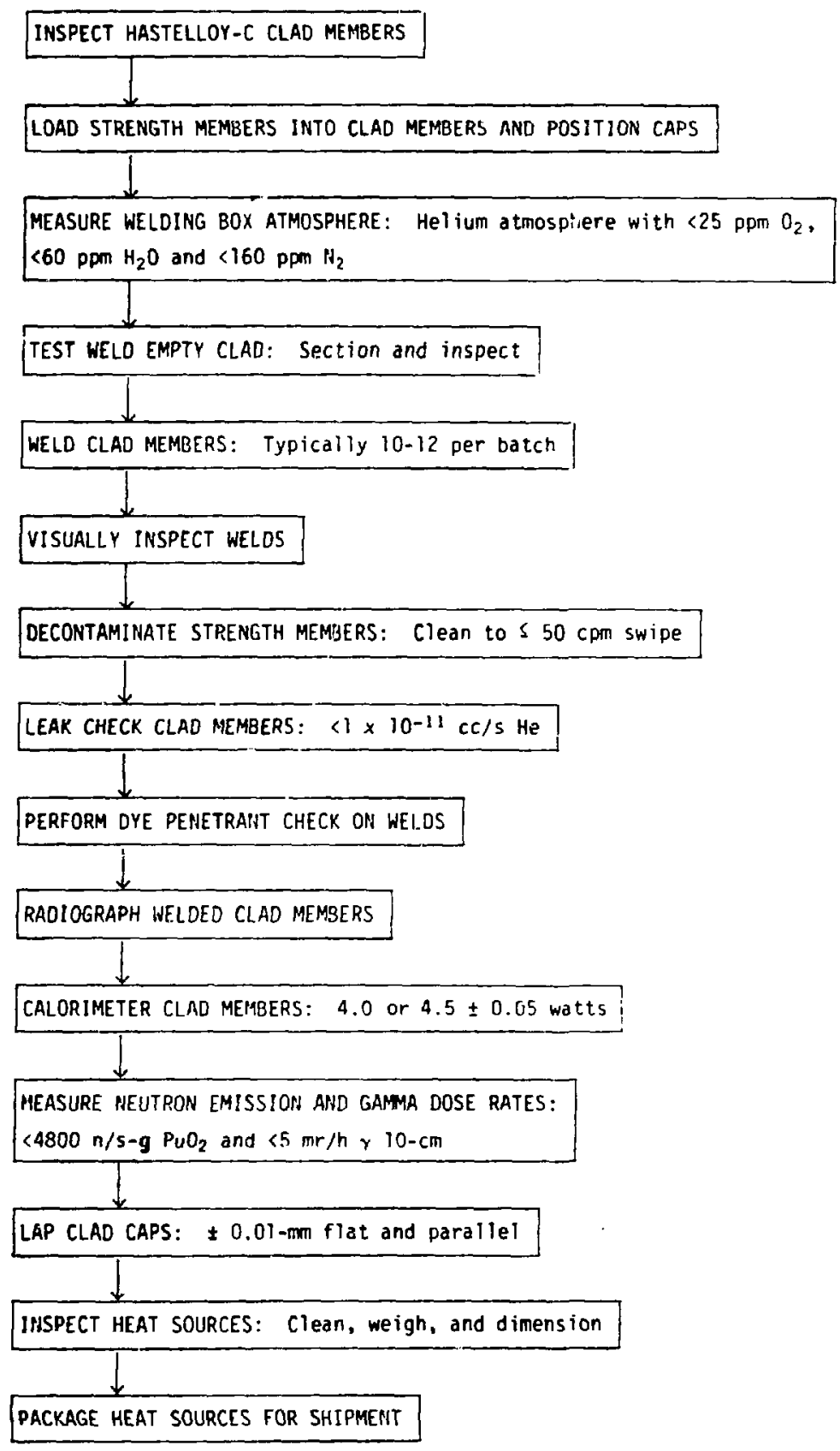

Fig. III-9. LASL MWG flowsheet - welding clad members. 
1. Gloveboxes. Two gloveboxes, separated by a decontanination hood and dedicated to the welding of MWG capsules, have been installed. Each box 15 provided with an independent inert-gas (helium) recirculating atmosphere that normally contains 0.5 to 2 ppm oxygen.

2. Welding Equipment. Two welding fixtures, built at LASL from modified MF drawings, have been installed in the inert-atmosphere welding gloveboxes. one is used for "hot" welds (liners), the other for "cold" welds (strength members and clads). The lixtures incorporate 12-position turret turntables which hold 12 capsules. Each turntable is provided with 3 sets of interchangeable collets to allow welding of liners, strergth members, and clads.

The Miller Analog 300 power supply with built-in current pulser and weld cycle programmer, together with the attendent controls, has been installed and tested and found to work satisfactorily.

3. Radiographic Measurements. The Balteau $400 \mathrm{kV}$ x-ray generator, shown in Fig. MI-10, has been received and tested. The tes results indicate that, with suitable masking, 4 MWG units can be radiographed simultaneously and with adequate resolution. A series of photographs for 4 WR heat sources, made at lifF, is shown in Fig. III-11. For the top row of photographs, the $x$-ray parameteris were set to enhance resolution of the strength member welds. For the lower low of photographs, the parameters were set to enhance resolution of the clad welds. Better results have been obtained by radingraphing the units after the strength member has been welded and then radiographing them again after the clar ha: bien welded.

4. Helium Leak Detection Measurements. Two helium leak detection systrms have been buitt and tested. Both systems incorporate Veeco MS-18 leak delectur:. provided with water cooling for the heat sources and with standard helium leak: calibrated at SNLA. One unit, operating iit the standard dynamic mode is ust:d is check welded liners to $5 \times 10^{-1 !} \mathrm{cm}^{3} / \mathrm{s}$ He. The other unit, shown in Fiq. !I!. 12, operates on the accumulation principle and is used to check welded streriyt? members and clads to $1 \times 10^{-11} \mathrm{~cm}^{3} / \mathrm{s}$. This unit works as follows. The specimens to be tested are loaded into one side of the manifold and the helium released (if any) is collected for a given time. Similarly, the helium released in the same tine period from a standard helium leak is collected in the other side of the manifold.

It is possible that either the strangth membar or the clad could have a leak in the weld area. However, if the fueled liner is leak-free, these leaks cannot be detected by a standard helium leak detector as no u particles will be released. Because of this, we have built a pressurization chamber capable of pressurizing a strength member or clad to $300 \mathrm{psi}$ with helium over $30 \mathrm{~min}$. The pressurized units can then be placed in distilled water to check for gros: leaks.

5. Ultrasonic Weld Inspection. A system, based on a KF USIP-11 analyzer has been buitt and tested. This system is shown in Fig. III-13. A new lackof-penetration (LOP) standard has been made from a $26-y$ pressure burst-test unit. The test parameters have been optimized to detect the $0.05-\mathrm{mm}$ and $0.1-\mathrm{mm}$ EOM notches in this standard.

6. Dye Penetrant Test. The techniques for checking welded capsules with fluorescent dye penetrant have been developed and the QA procedures have been written and approved. 


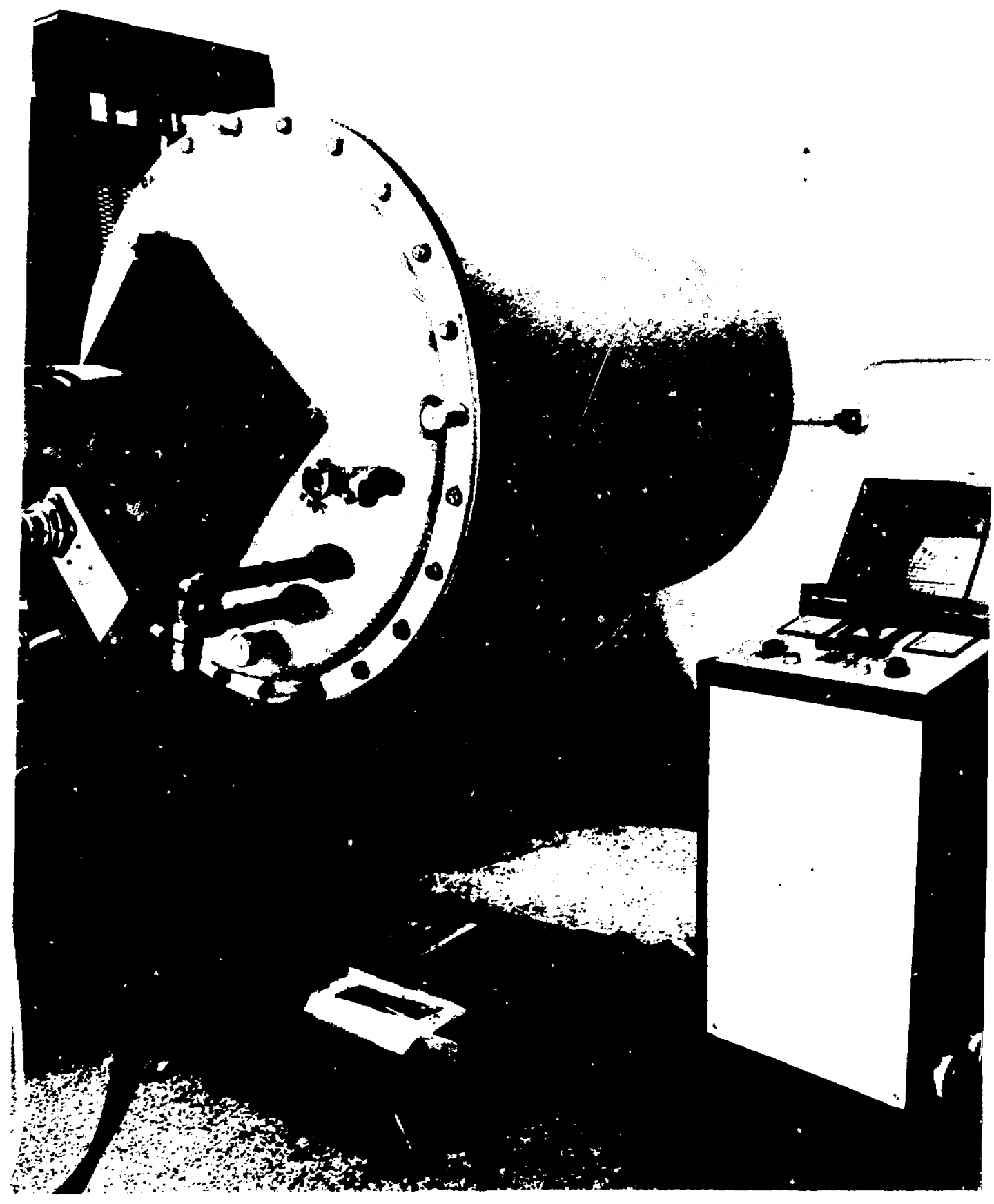

Fig. III-10. Balteau $400 \mathrm{kV} \times$-ray generator. 


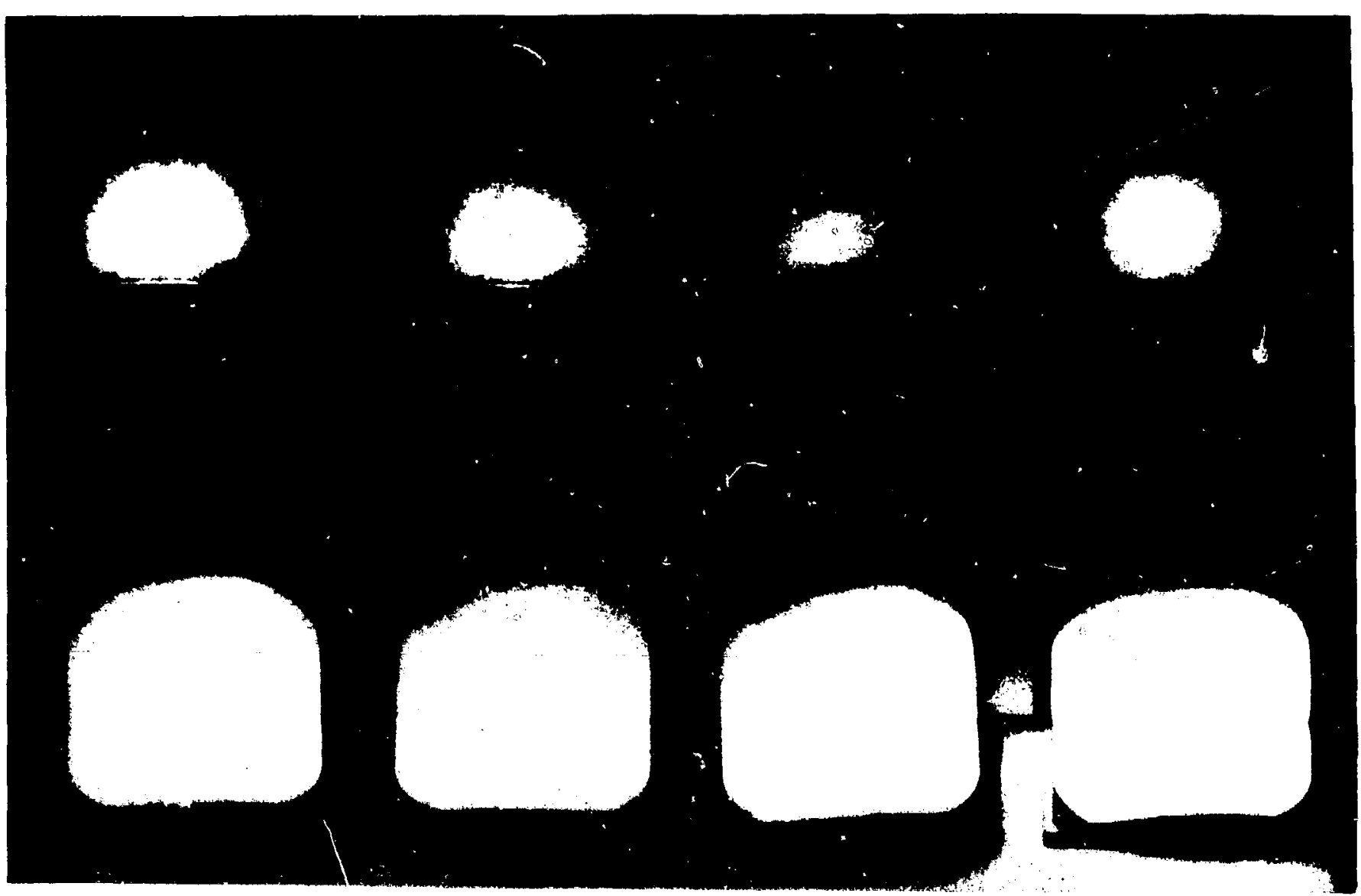

Fig. III-11. Radiography results for MF heat sources, left to right MAD-805, -804, -803 , and -802 . The top row emphasizes the strength member weids, the bottom row the clad welds. 


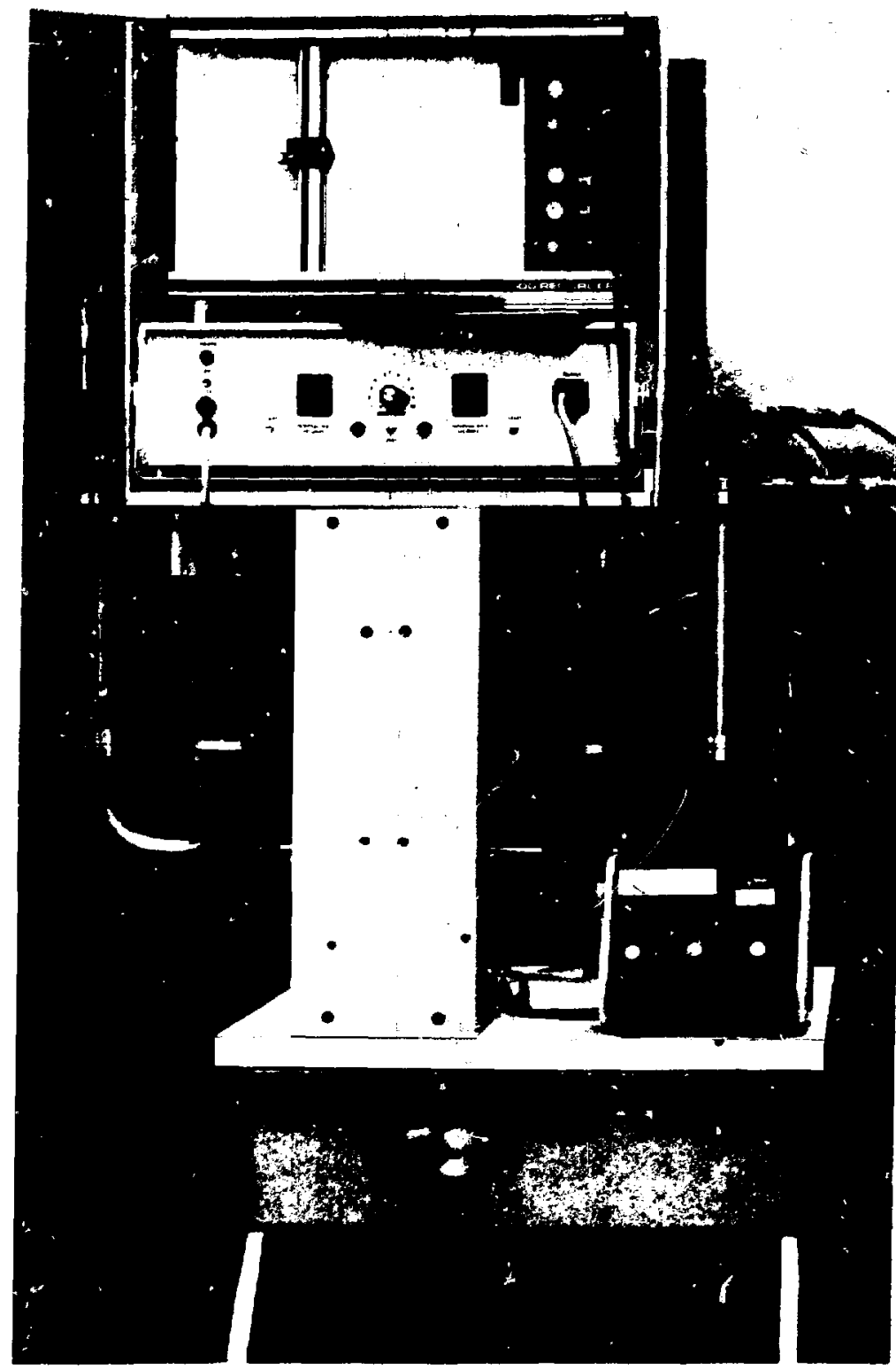

Fig. III-12. Accumulation-type leak detector for testing strength member and clad welds. 


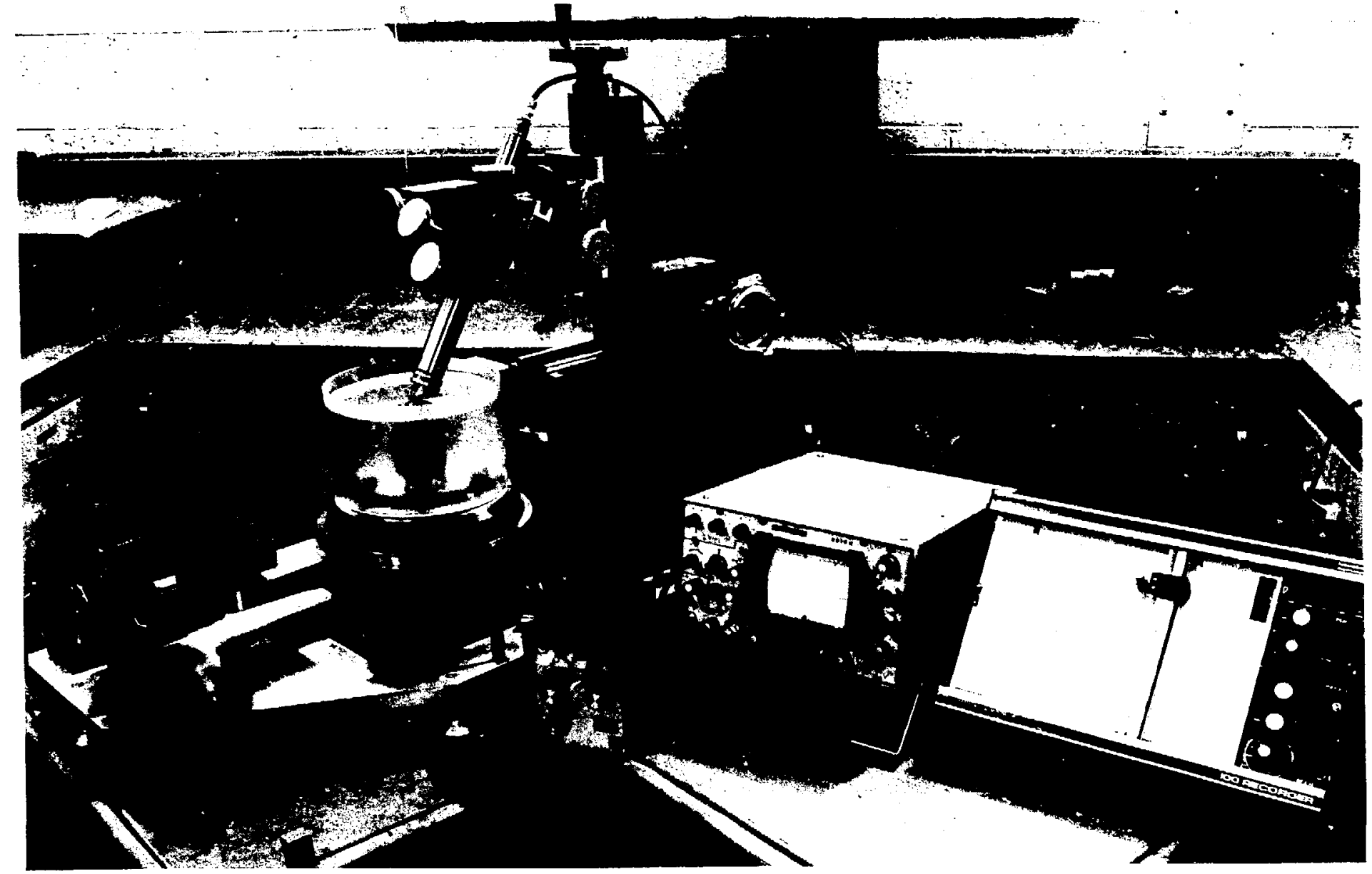

Fig. III-13. Ultrasonic weld inspection system. 
7. Clad Member Lapping. A Buehler Ltd. Model ECOMET III polisher/grinder has been installed for lapping the clad member caps (after welding) to a surface fltaness of $\pm 0.01 \mathrm{~mm}$. Six heat sources can be lapped at a time. Successful results have been obtained by polishing the caps for 20 min with $20-\mu m$ alumina. A Brown and Sharpe electronic gauging system has been received and tested. This unit is capable of measuring surface flatness variations as small as $4 \times 10^{-5}$ $\mathrm{mm}$.

\section{DESTRUCTIVE TESTING}

A. Pressure Burst Units

Four LASL pressure burst-test capsules, LASL-01, $-36,-37$, and -38 , were sectioned and the weld areas were examined metallographically. The weld structures for these capsules are shown in Fig. IV-1 through Fig. IV-9. All welds had fully penetrated with an average thickness of $1.47 \mathrm{~mm}$. No defects such as gas bubbles were observed. The average oxygen and nitrogen contents in the weld areas were 39 and $18 \mathrm{ppm}$, respectively. The average hardness for the weld areas was 244 (UHN). These values are approximately the same as those obtained for WR capsules, made at MF, listed in Table IV-1 through IV-3.

B. Impacted WR Capsules

Two WR heat sources, MAD-802-1-78 and MAD-804-1-78, were impacted at LASL at $450^{\circ} \mathrm{C}$ and at 148 and $150 \mathrm{~m} / \mathrm{s}$, respectively. The clad weld breached for each capsule but both strength members remained intact. The macrographs for capsule MAD-802. are shown in Fig. IV-10 through IV-15. The liner for capsule MAD-802 remained intact while necking to $0.05 \mathrm{~mm}$ in the dome area, Fig. IV-12 and Fig. IV-15. However, it failed intergranularly in a brittle manier in the weld, Fig. IV-13 and Fig. IV-14, at the corner of the impact face.

The macrographs for capsule MAD-804 are shown in Fig. IV-16 through Fig. IV-19. The liner for this capsule necked to $0.03 \mathrm{~mm}$ in the dome area but remained intact.

Analytical data for these capsules are summarized in Table IV-1 through Table IV-3. Impact results for capsules MAD-802 and MAD-804 are summarized in Table IV-4, together with data for capsulg MAD-801 and simulant capsule WMYT-01, impacted at LASL and reported previously.

C. Nonimpacted WR Capsules

Two WR heat sources made at MF, MAD-800-I-78 and MAD-805-1-78, were sectioned in the as-received condition. The macrographs are shown in Fig. IV-20 through Fig. IV-24. No flaws were detected for MAD-800. However, Fig. IV -24 indicates the possibility of a grain-boundary impurity phase at the edge of the liner weld for MAD-805. Analytical data for these capsules are listed in Table IV-1 through Table IV-3. 


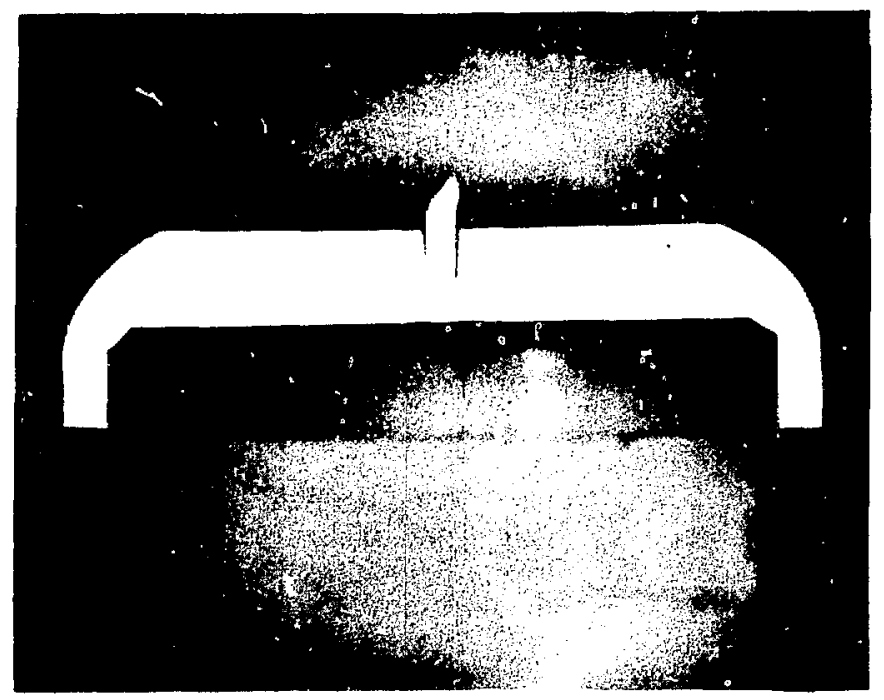

Fig. IV-1. Cross section of pressure burst capsiTe LASL-DI, $4-\frac{1}{2} X$.

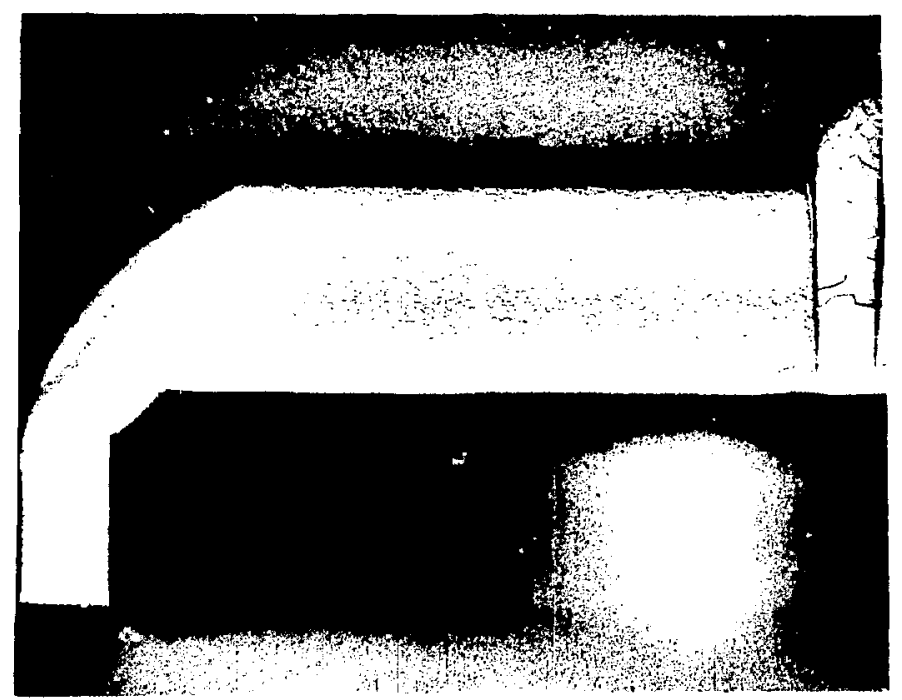

Fia. IV-2. Cross section of pressure burst capsule LASL-01, AE, 10X. 


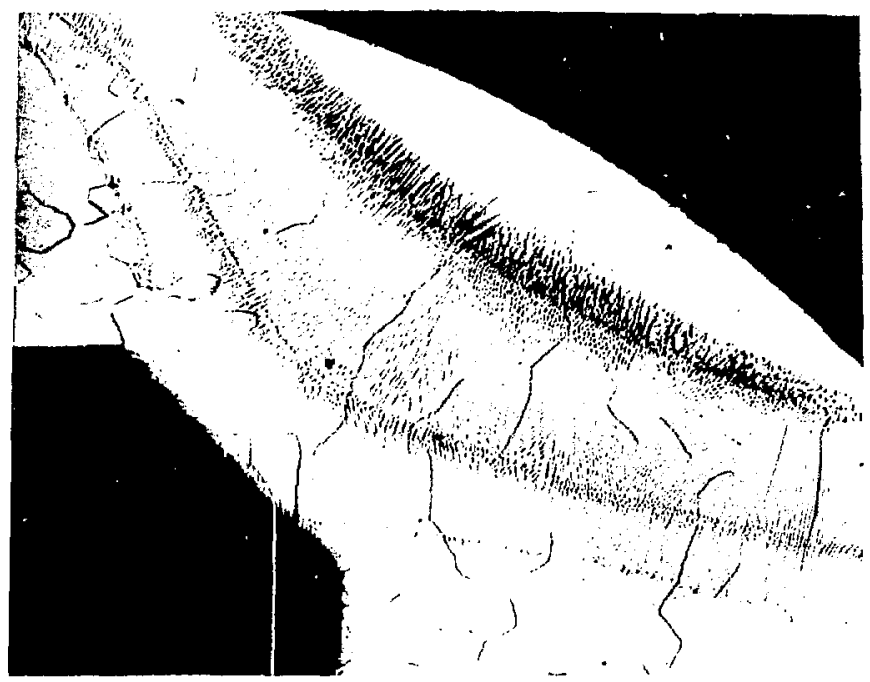

Fig. IV-3. WeId area of pressure burst capsule LASIL-01, AE, 40X.

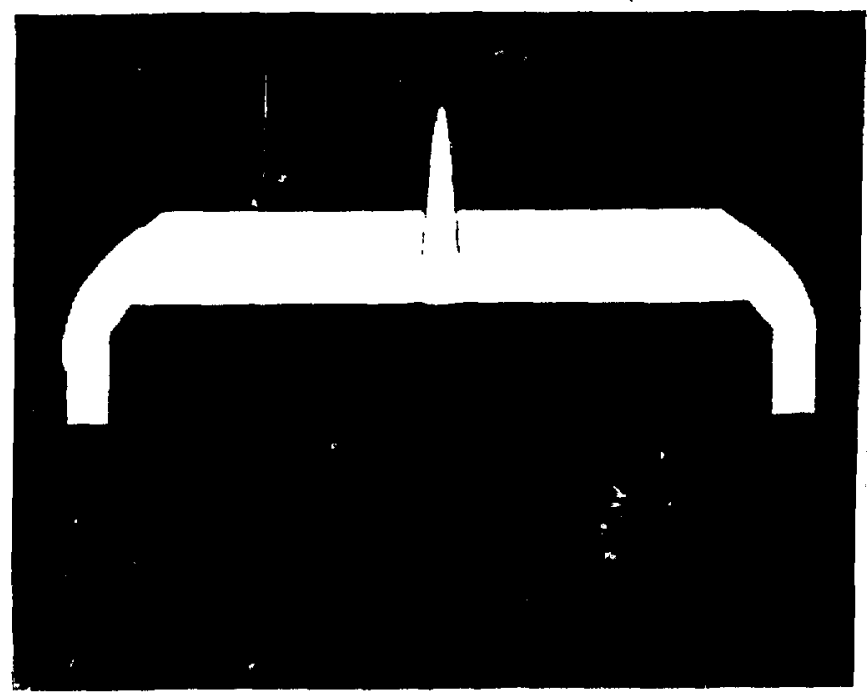

Fig. IV-4. Cross section of pressure burst

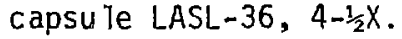




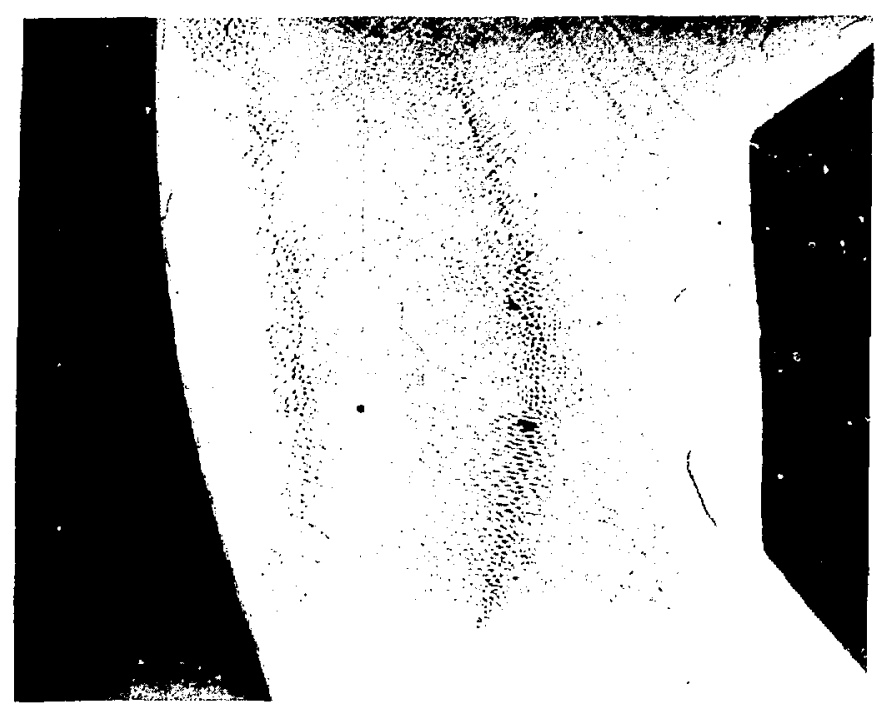

Fig. IV-5. Weld area of pressure burst capsule LASL-36, AE, 50X.

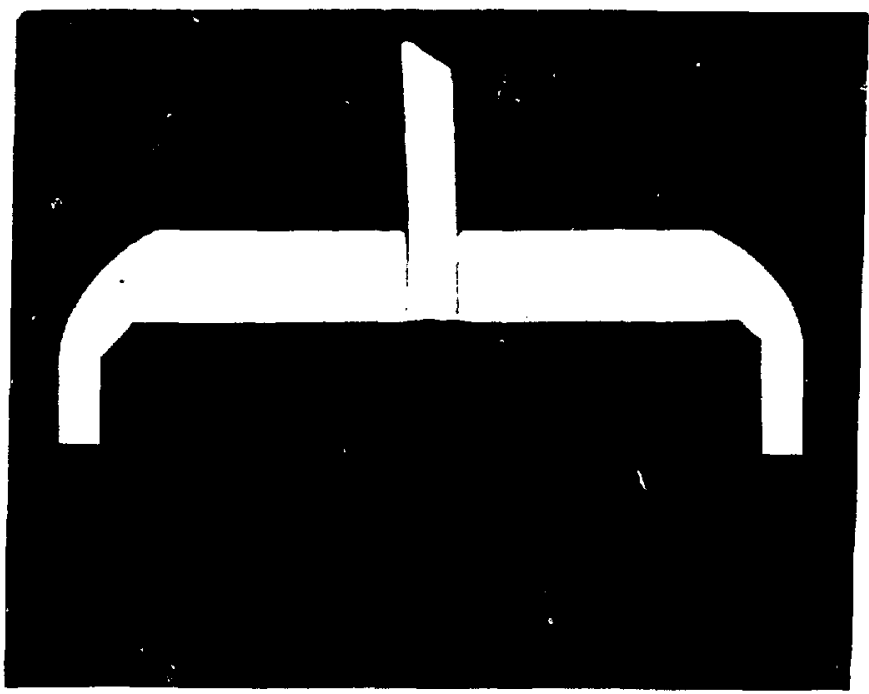

Fig. IV-6. Cross section of pressure burst

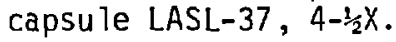




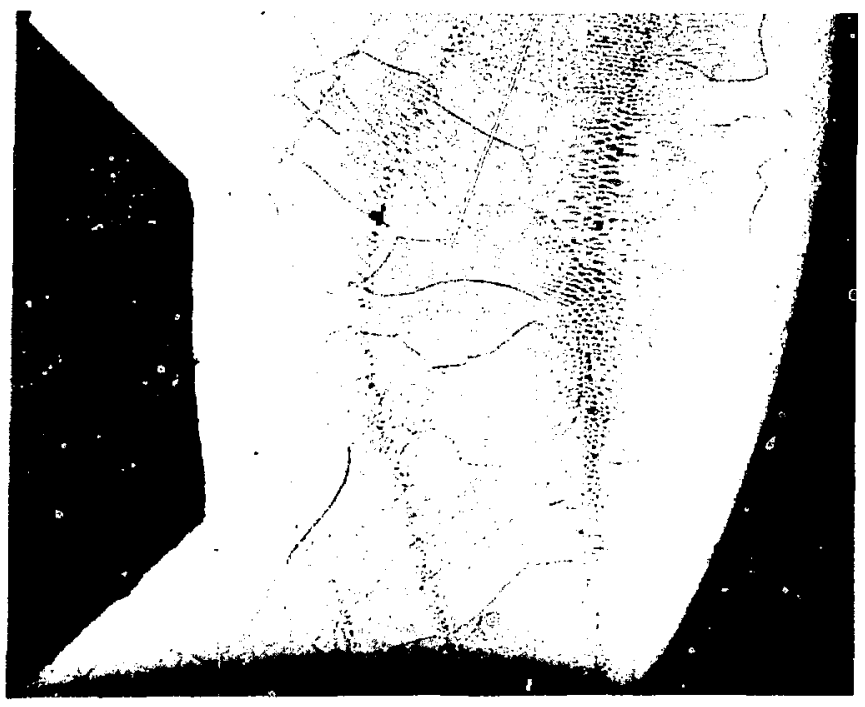

Fig. IV-7. Weld area of pressure burst capsule LASL-37, AE, 50X.

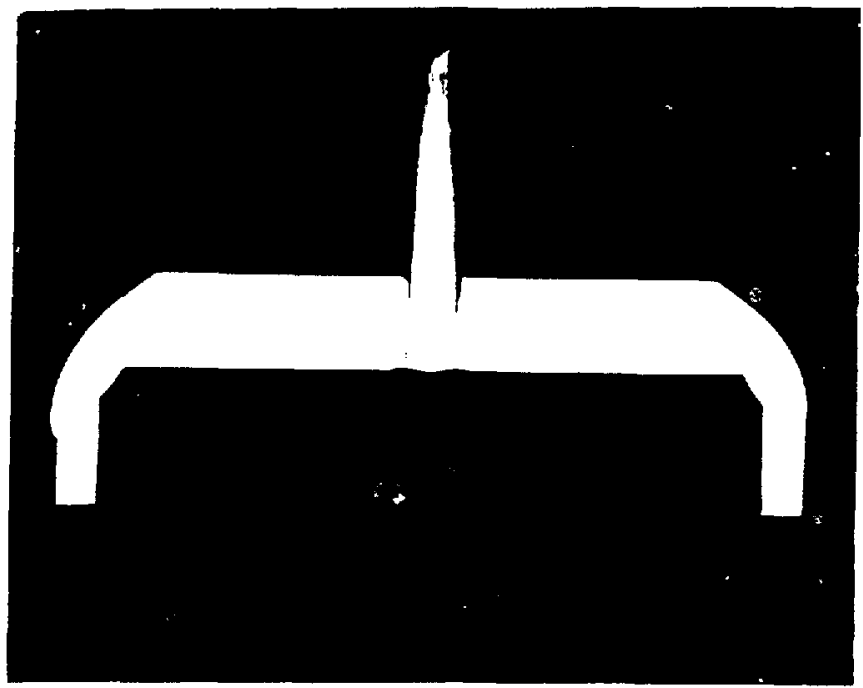

Fig. IV-8. Cross section of pressure burst capsu Te LASL-38, 4-1/2X. 


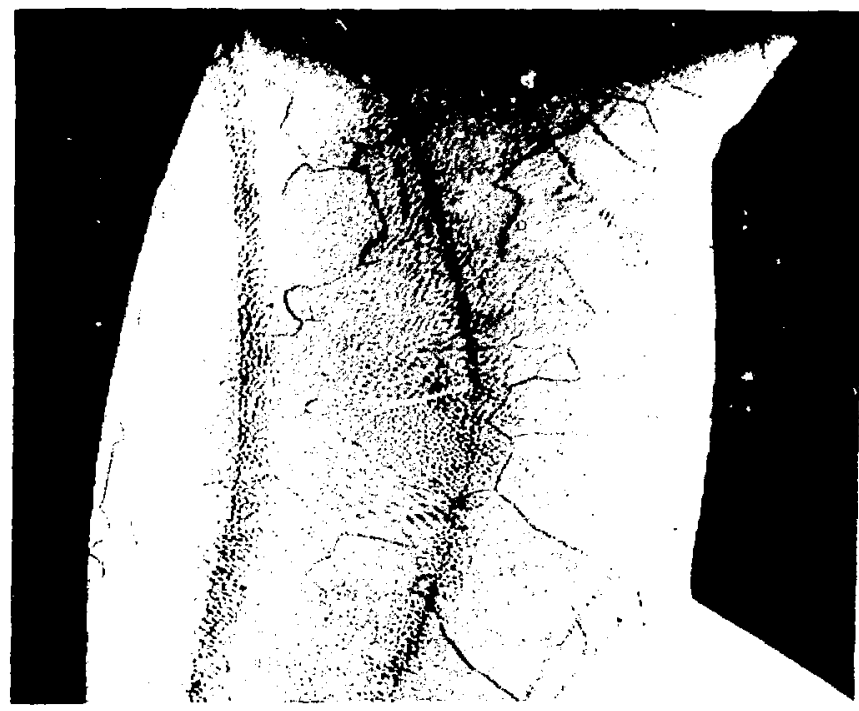

Fig. IV-9. Weld area of pressure burst capsule LASL-38, AE, 50X. 


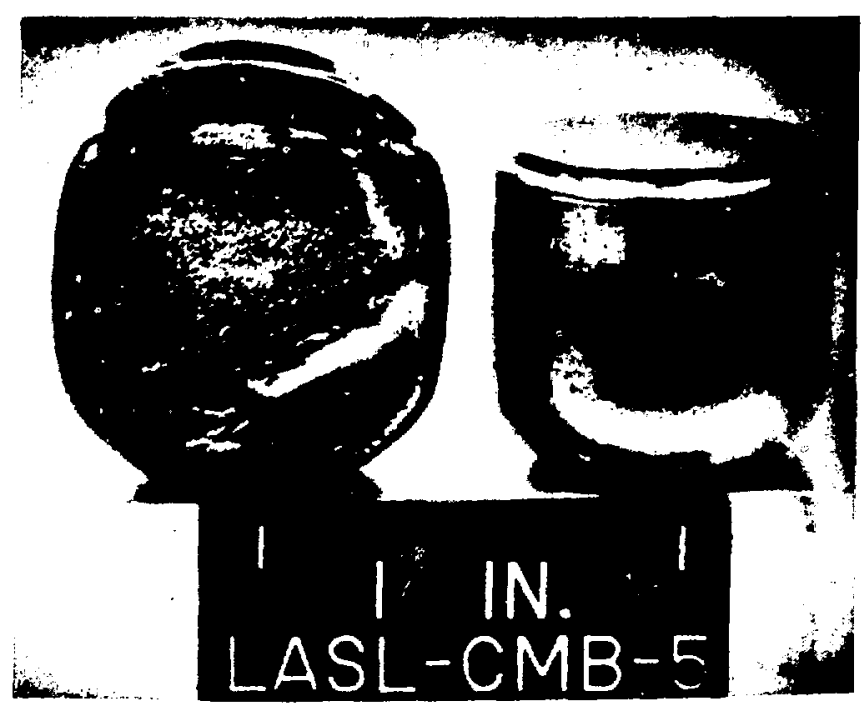

Fig. IV-10. Impact face of MAD-802 after impact, $2 x$, simulant capsule WYMT-02 on right.

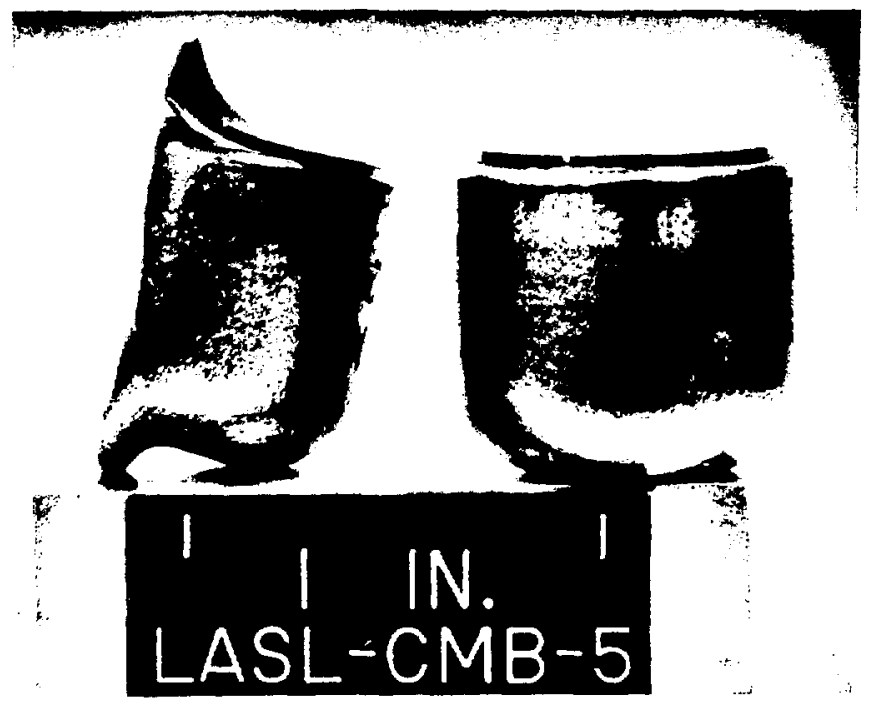

Fig. IV-11. MAD-802 after impact, $90^{\circ}$ to impact face, $2 X$, simulant capsule WYMT -02 on right. 


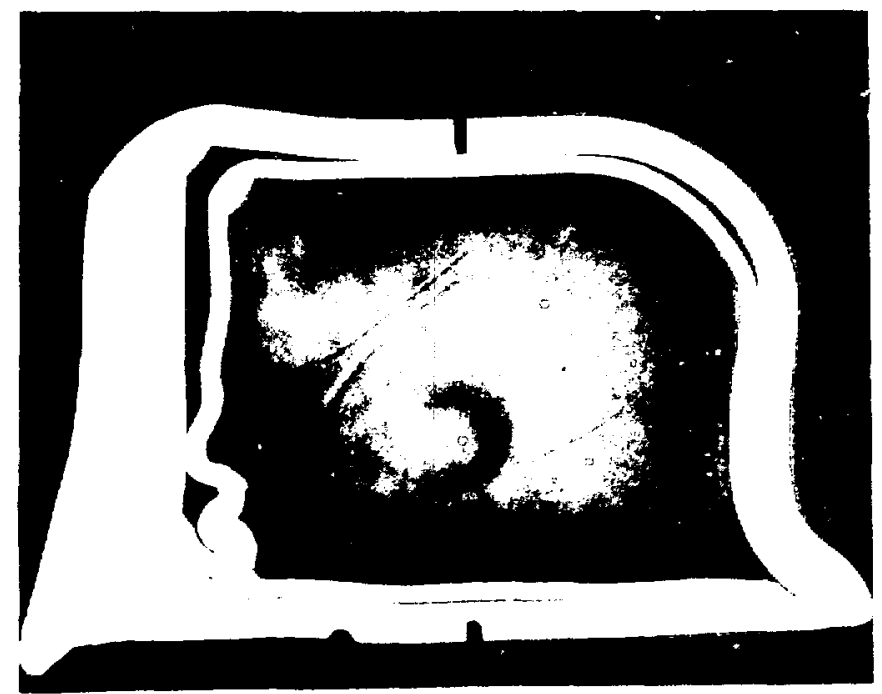

Fig. IV-12. Cross section of MAD-802 after impact, showing liner inside strength member, $4-\frac{1}{2} X$.

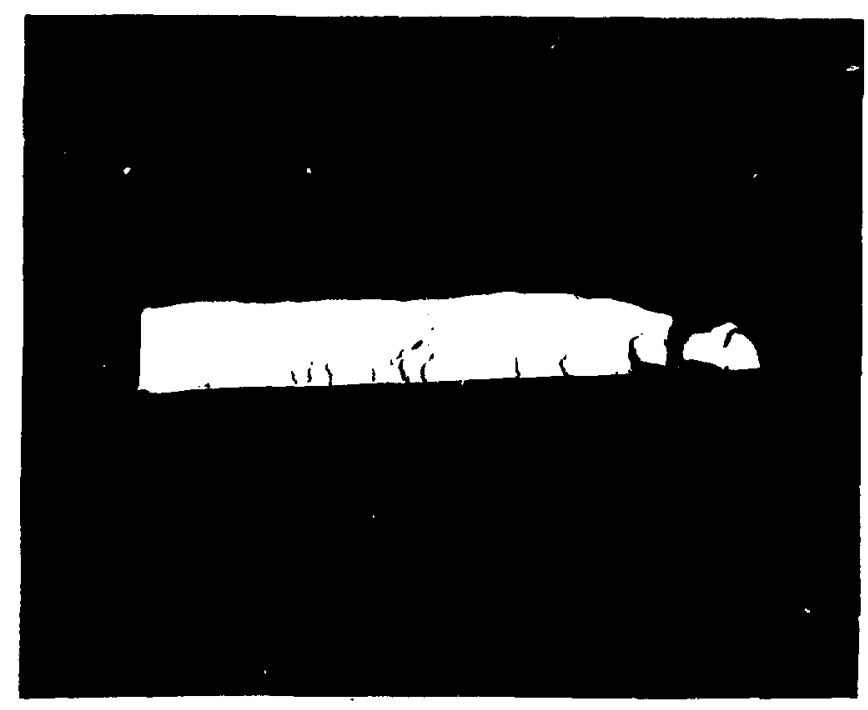

Fig. IV-13. Liner weld of MAD-802 after impact, $8 x$. 


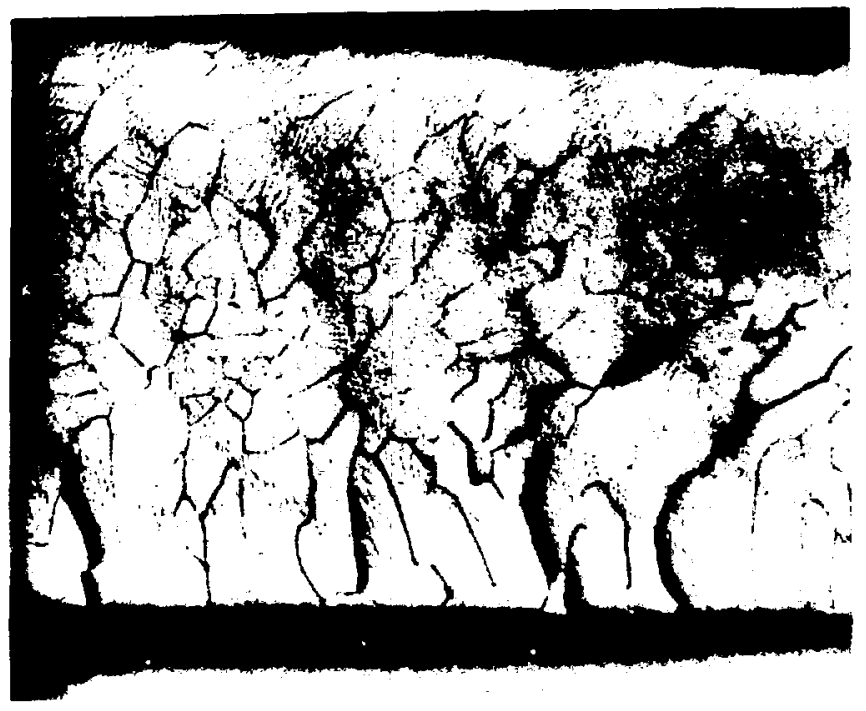

Fig. IV-14. Liner weld of MAD-802, after impact, $A E, 50 X$.

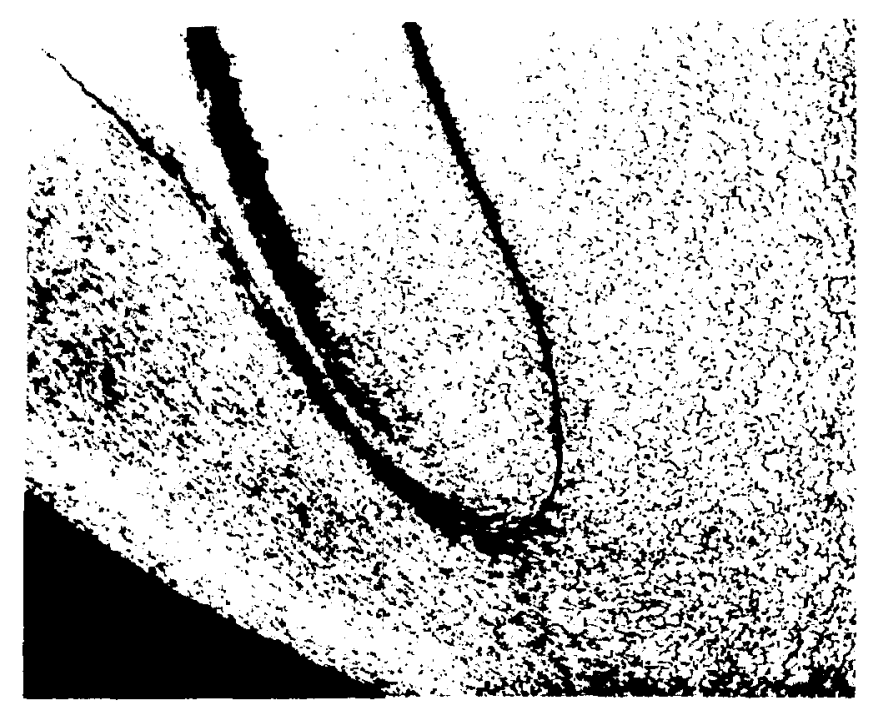

Fig. IV-15. Dome of MAD-802 after impact, AE, $50 x$. 


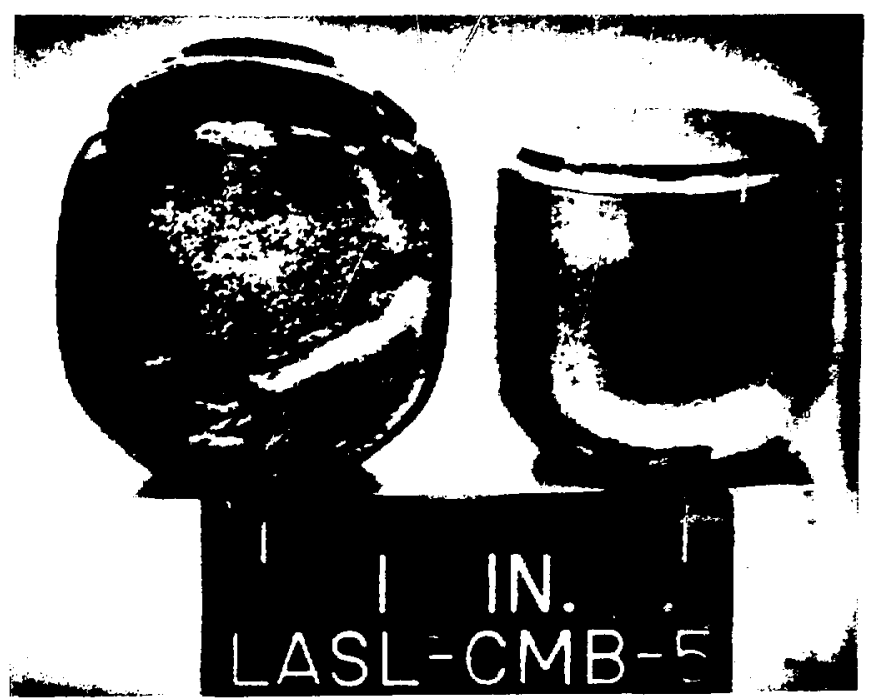

Fig. IV-16. Impact face of MAD-804 after impact, $2 X$, simulant capsule WYMT-02 on right.

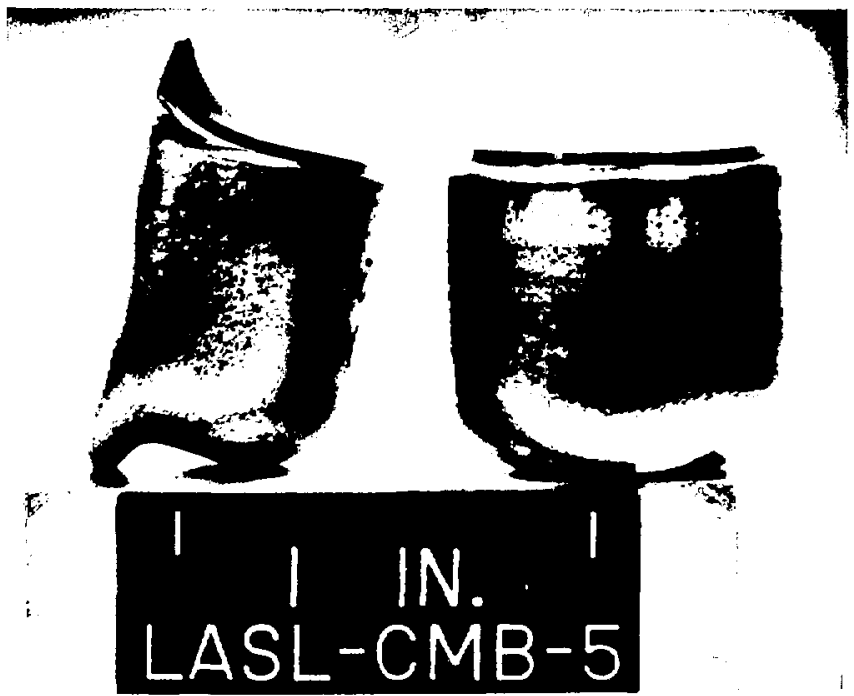

Fig. IV-17. MAD-804 after impact, $90^{\circ}$ to impact face, $2 X$, simu lant capsule WYMT-02 on right. 


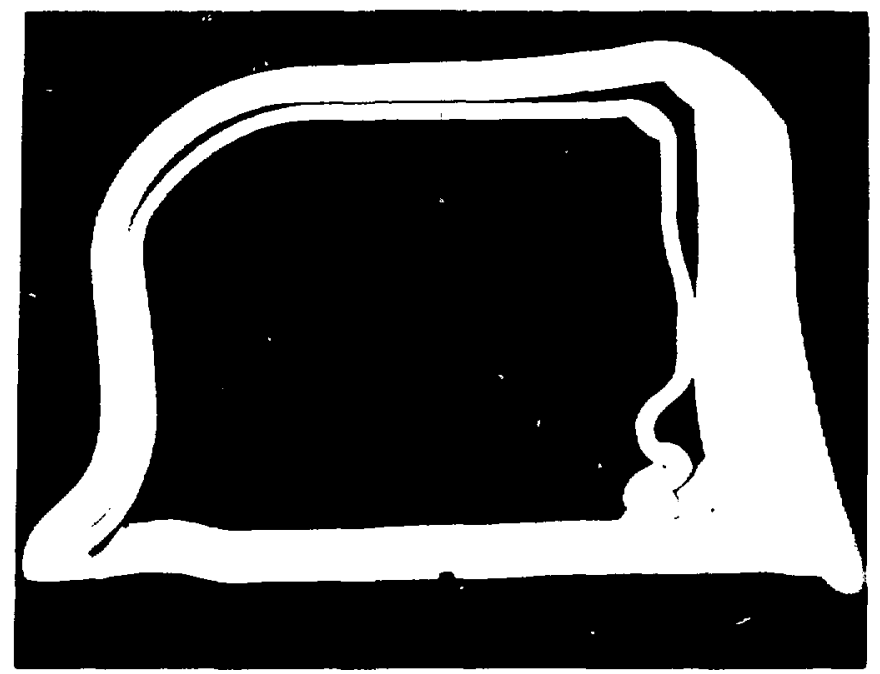

Fig. IV-18. Cross section of MAD-804 after impact, showing liner inside strenoth member, $4-1, x$.

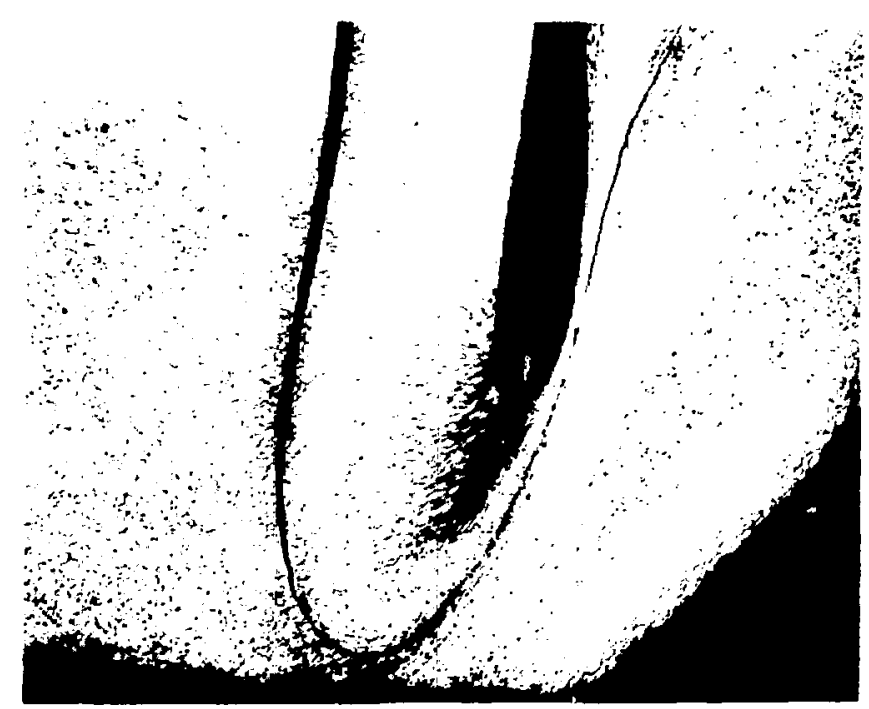

Fig. IV-72. Dame of MAD-804 after impact, AE, $50 x$. 


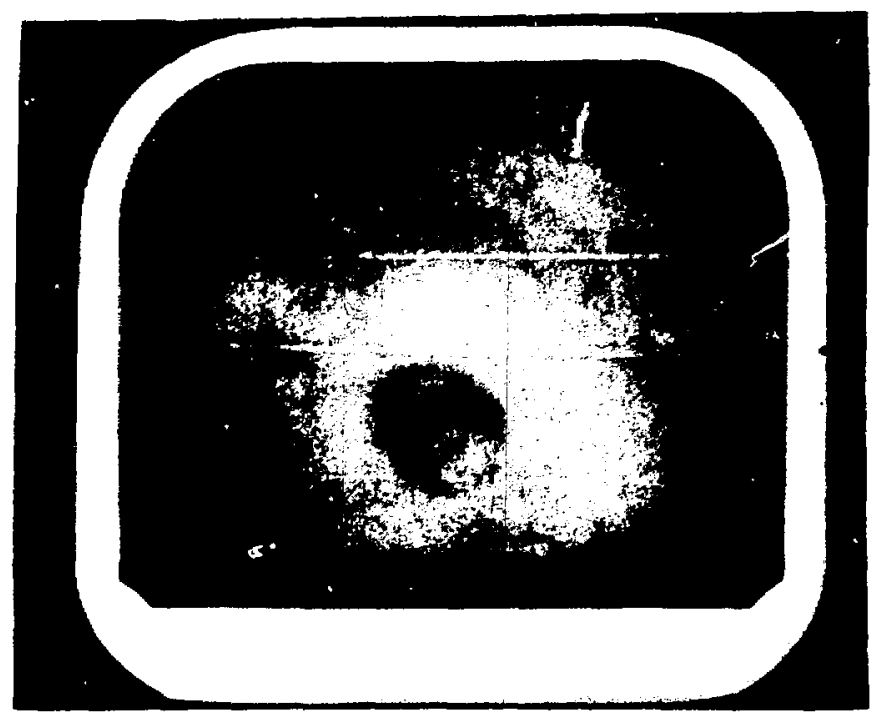

Fig. IV-20. Cross section of strength member for MAD-800, 4- $\frac{1}{2} X$.

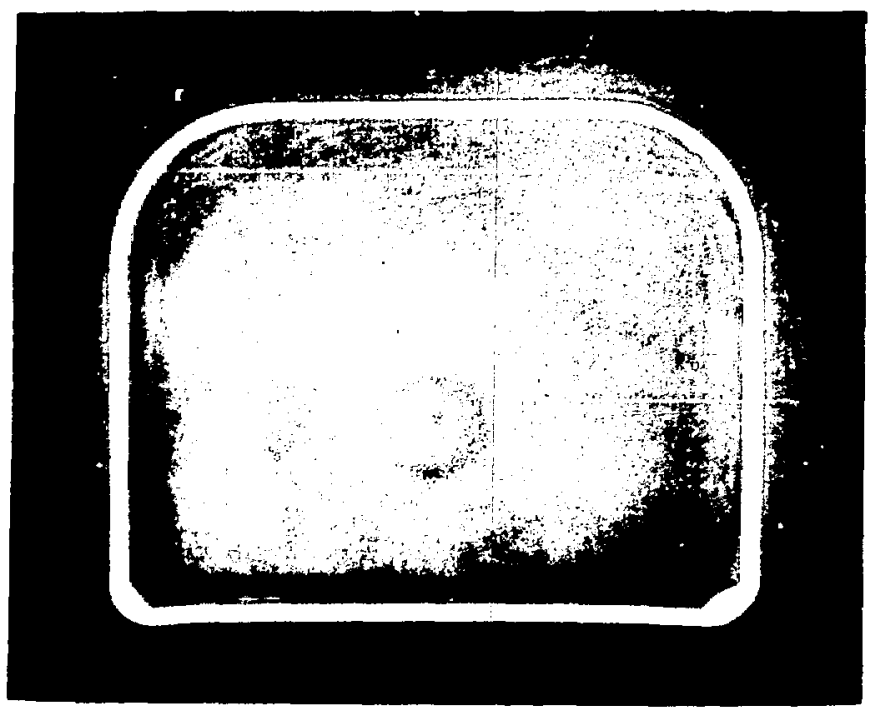

Fig. IV-21. Cross section of liner for MAD-800, $4-\frac{1}{2} X$. 


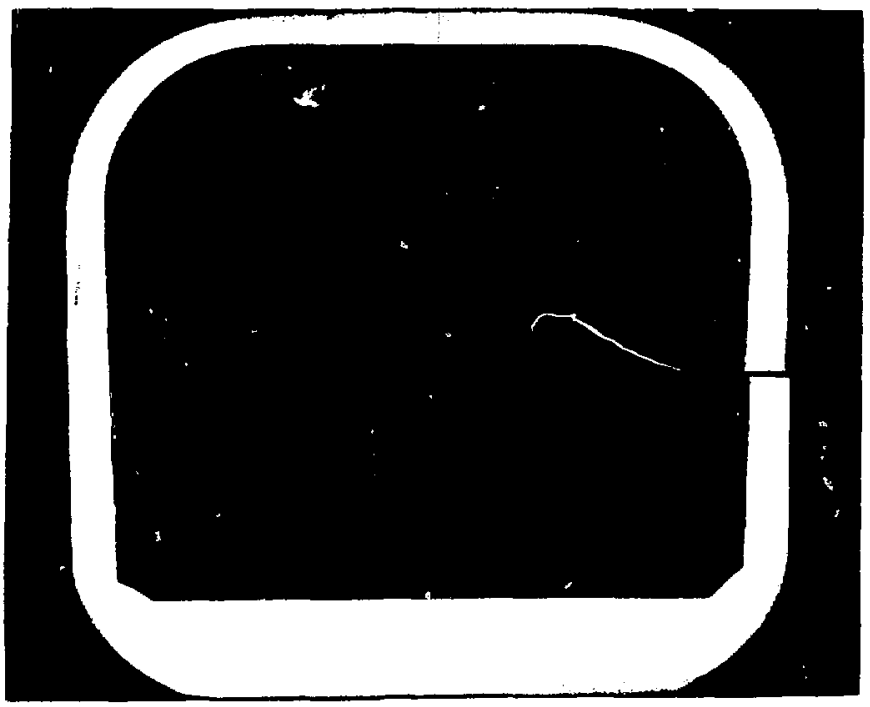

Fig. IV-22. Cross section of strength member for MAD-805, 4- $\frac{1}{2} X$.

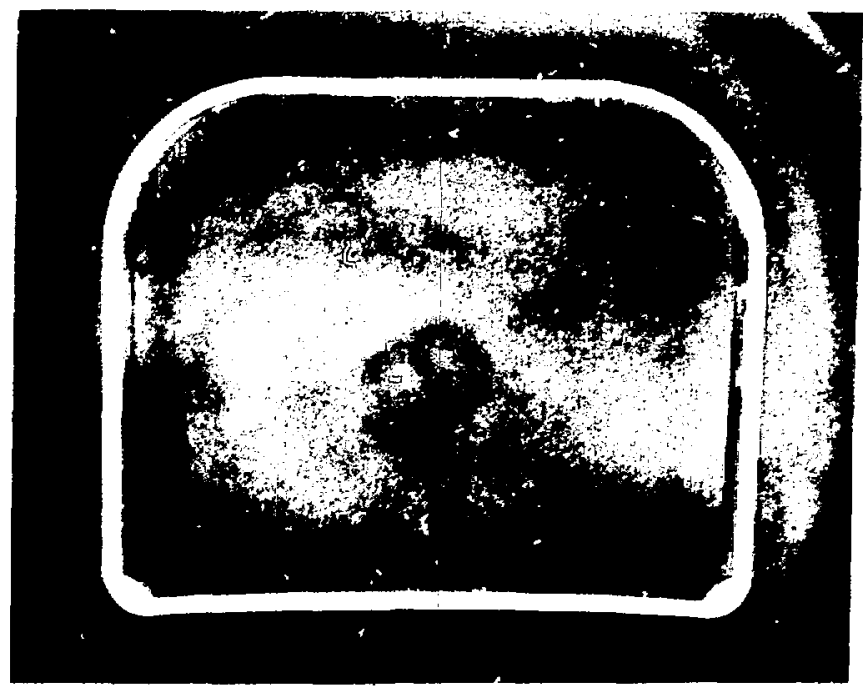

Fig. IV-23. Cross section of liner for MAD-805, $4-\frac{1}{2} X$. 


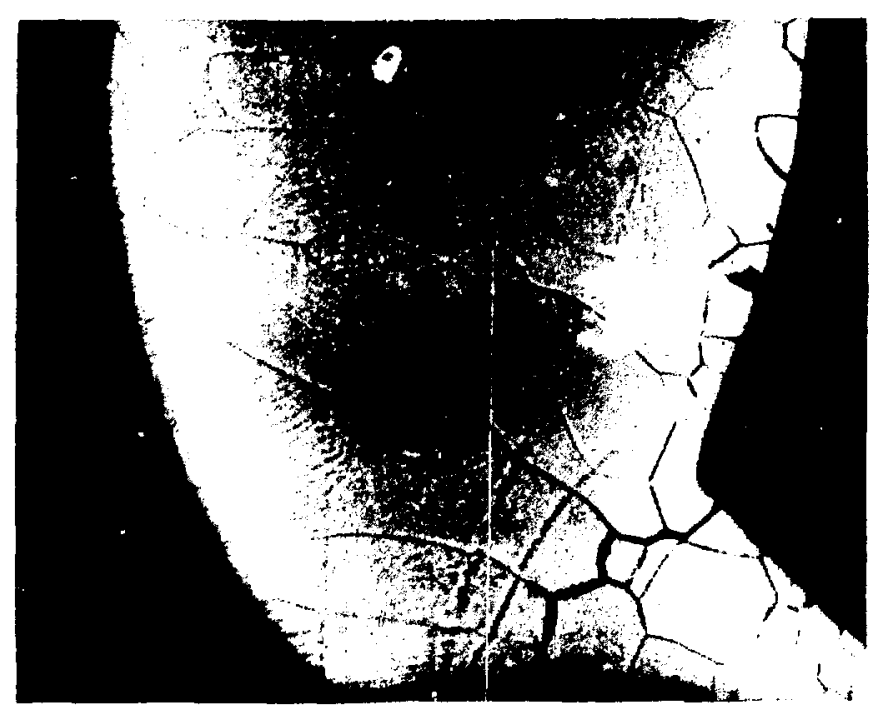

Fig. IV-24. Liner weld area of MAD-805, AE, 100X. 
TABLE IV-1

ANALYTICAL DATA FOR MWG CAPSULES

OXYGEN

(ppm by weight)

\begin{tabular}{|c|c|c|c|c|c|c|c|}
\hline \multirow[b]{2}{*}{ Number } & \multirow[b]{2}{*}{ Type } & \multicolumn{3}{|c|}{ Liner } & \multicolumn{3}{|c|}{ Strength Member } \\
\hline & & Body & Dome & WeTd & Body & Dome & WeTd \\
\hline MAD- 800 & WR & 350 & 180 & $\begin{array}{l}35 \\
30\end{array}$ & 35 & 30 & $\begin{array}{l}35 \\
25\end{array}$ \\
\hline MAD-801 & $W R$ & 190 & 680 & 30 & 20 & 20 & 35 \\
\hline MAD-802 & Wh & 120 & 180 & 40 & 30 & 25 & 30 \\
\hline MAD-804 & WR & 120 & 240 & 35 & 25 & 30 & 20 \\
\hline MAD-805 & WR & 90 & 190 & 70 & 35 & 35 & 40 \\
\hline WMYT T-01 & Simulant & 65 & 190 & 50 & 50 & 60 & 45 \\
\hline LASL-01 & Burst Test & & & & & & \\
\hline LASL- 36 & Burst Test & & & & & & 50 \\
\hline LAS & Burst Test & & & & & & 30 \\
\hline LASL-38 & Burst Test & & & & & & 30 \\
\hline
\end{tabular}

TABLE IV-2

ANALYTICAL DAIA FOR MWG CAPSULES

NITROGEN

(ppm by weight)

MAD-800

MAD- 801

MAD-802

MAD-804

MAD- 805

WMYT 01

LASL-01

LASL -36

LASL -37

LASL -38

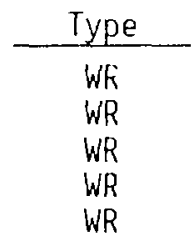

Bod
130
25
40
30

Liner

\begin{tabular}{rr} 
Dome & Weld \\
\cline { 2 - 2 } 155 & 105 \\
50 & 55 \\
20 & 45 \\
- & 35 \\
25 & 20 \\
15 & 10 \\
& 15 \\
& 20 \\
& 20 \\
& 15
\end{tabular}

Strength Member

Body Dome WeTd

$\begin{array}{lll}70 & 65 & 55\end{array}$

$\begin{array}{lll}42 & 27 & 33\end{array}$

$\begin{array}{lll}25 & 25 & 25\end{array}$

$30 \quad 25 \quad 30$

Simulant $<10-15<10<10<10$

Burst Test

Burst Test

Burst Test

20
15 
TABLE IV-3

ANALYTICAL DATA FOR MWG CAPSULES

HARDNESS

(UHN)

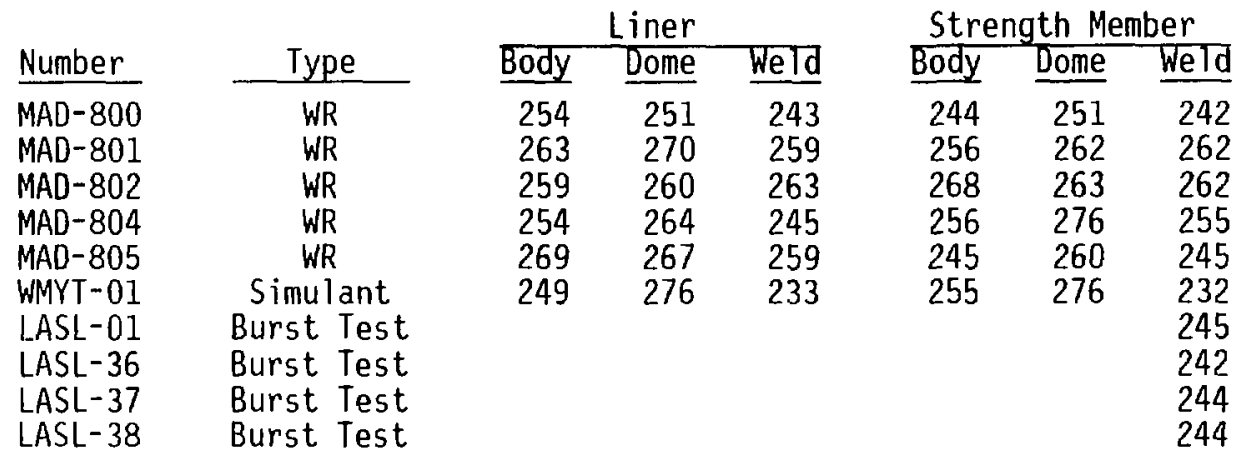

\section{QUALITY ASSURANCE}

A. Internal Documents

The planning documents written and approved for the MWG Project include (1) QA Program Plan, (2) Fabrication, Inspection, and Test Plan, (3) Personnel Qualification and Certification, (4) Procurement, (5) Specification Exception Release, (6) Change Control, (7) Document Control and (8) Submission of material to DOE. Approximately 50 processing procedures have been written for the assembly and testing of fueled heat sources. These are being tested and evaluated during the fabrication of the test units described in Section I, above. Personnel will be trained and certified for the latest revisions of these procedures prior to the LASL Tool Made Sample (TMS) audit. The identification numbers and titles for the processing procedures are summarized in the Fabrication, Inspection, and Test Plan, MWG-CMB-PD-1.

B. Interface Documents

The existing QA program drawings have been reviewed and modified by LASL and SNLA personnel. The Technical Information Exchange (TIE) Agreement has been approved and signed by the appropriate LASL and SNLA personnel.

\section{MEETINGS}

On May 1, 1980, a MWG Review Meeting was held at LASL. Outside attendees were C. A. Richardson and C. Smith (DOE/ALO) and R. T. Jankowski, W. J. Kass, and $N$. A. Branson (SNLA). LASL attendees were C. E. Frantz and C. C. Land $(C M B-5)$, R. R. Geoffrion (CMB-QA), and R. G. Behrens, G. H. Rinehart, W. A. Stark and R. A. Kent (CMB-11). 
On June 12, 1980, R. T. Jankowski, P. Syroid and N. A. Branson (SNLA) visited LASL.

On July 23,1980, R. T. Jankowski and T. Young (SNLA) visited LASL.

On August 22, 1980, C. Garcia (DOE/ALO) and R. T. Jankowski, T. Young, and N. A. Branson (SNLA) visited LASL.

On September 23-24, 1980, a MWG Review meeting was held at MF. LASL attendees were R. D. Strong $(M-5)$, R. R. Geoffrion and J. H. Kottmann (CMB-QA), C. C. Land (CMB-5), and E. D. Brandon, R. G. Behrens, G. H. Rinehart, W. A. Stark, and R. A. Kent (CMB-11).

\section{REFERENCES}

1. L. Prosser, Mounds Facility, Monsanto Research Corporation, unpublished data, 1980.

2. "Milliwatt Generator Project, October 1979 - April 1980," Los Alamos Scientific Laboratory Report LA-8406-PR (June 1980). 
TABLE IV-4

IMPACT TEST RESULIS

\begin{tabular}{|c|c|c|c|c|c|c|c|}
\hline \multirow[b]{2}{*}{ Number } & \multirow[b]{2}{*}{ Type } & \multirow[b]{2}{*}{$\begin{array}{l}\text { Impact Velocity } \\
(\mathrm{m} / \mathrm{s})\end{array}$} & \multirow{2}{*}{\multicolumn{2}{|c|}{ Percent Diametral Strain }} & \multicolumn{3}{|c|}{ Results } \\
\hline & & & & & Clad & $\begin{array}{l}\text { Strength } \\
\text { Member }\end{array}$ & Liner \\
\hline MAD- 801 & WR & 150 & 25.0 & 17.1 & Breach & Intact & Intact \\
\hline MAD-802 & WR & 148 & 26.2 & 16.4 & Breach & Intact & Failed at weld \\
\hline MAD-804 & WR & 150 & 25.6 & 14.0 & Breach & Intact & Intact \\
\hline MYYT-01 & Simulant & 149 & 25.0 & 17.1 & Breach & Intact & Failed at weld \\
\hline
\end{tabular}

